\title{
Household Formation Over Time: Evidence from Two Cohorts of Young Adults
}

\author{
Daniel Cooper and Maria José Luengo-Prado
}

\begin{abstract}
:
This policy brief analyzes household formation in the United States using data from two cohorts of the National Longitudinal Survey of Youth (NLSY) - the 1979 cohort and the 1997 cohort. The analysis focuses on how various demographic and economic factors impact household formation both within cohorts and over time across cohorts. The results show that there are substantial differences in the share of young adults living with their parents over time. Differences in housing costs and business cycle conditions explain nearly 45 percent of the difference in household formation rates across cohorts; however, some of the slowdown in household formation remains unexplained. In addition, none of the observed factors that impact household formation likely can fully account for the rather abrupt slowdown in the rate of U.S. household formation starting around 2006.
\end{abstract}

\section{JEL Classification: J11, E24, R21}

Daniel Cooper and Maria José Luengo-Prado are both senior economists and policy advisors in the research department of the Federal Reserve Bank of Boston. Their e-mail addresses are daniel.cooper@bos.frb.org and maria.luengo-prado@bos.frb.org.

We would like to thank Giovanni Olivei for helpful comments and Sarah Freitas, Ye Ji Kee, and Chloe Lee for research assistance. All errors are our own.

This paper presents preliminary analysis and results intended to stimulate discussion and critical comment. The views expressed herein are those of the authors and do not indicate concurrence by the Federal Reserve Bank of Boston, the Bureau of Labor Statistics, the principals of the Board of Governors, or the Federal Reserve System.

This paper, which may be revised, is available on the web site of the Federal Reserve Bank of Boston at http://www.bostonfed.org/economic/current-policy-perspectives/index.htm.

This version: November 2, 2015 


\section{Introduction}

Following the Great Recession, U.S. residential investment has improved slowly-despite a relatively strong rebound in national house prices (see Figure 1). The sluggish recovery in residential investment is often cited as one of the reasons for the tepid U.S. economic recovery. An important factor for determining and predicting U.S. residential investment is the pace of household formation - the rate at which members of existing households leave to form their own households, less the rate at which existing households combine. Indeed, as shown in Figure 2, the current number of U.S. households is well below its pre-recession trend (dashed line). This trend line takes the age-based population share of households in 2001 as given, and projects the expected annual number of households based on these shares and age-based shifts in the U.S. population. ${ }^{1}$ Re-evaluating the trend based on post-recession data on the number of households by age group in 2009 shows a downward shift in the projected number of U.S. households (dotted line), but the actual number of households remains well below trend. This evidence implies that new households in the United States continue to form at a below-trend rate.

Residential investment is tied to household formation because new units are built to meet the population's housing demands. With households forming at a slower rate than in the period before the Great Recession, there is less demand for housing and hence less construction and residential investment. ${ }^{2}$ Household formation is driven largely by young adults moving out of their parents' homes after high school or college-however, household members can separate from parental or other co-residential living situations and form new households at any age due to marriage, divorce, or other factors. New household formation can be offset by existing households combining (for example through marriage) or, as has occurred more recently, by individuals moving back home to live with their parents or other relatives for economic reasons.

This policy brief uses individual-level data from two different cohorts (1979 and 1997) of the National Longitudinal Survey of Youth (NLSY) to examine the factors that impact whether or not a young adult decides to form his/her own household rather than living with (his/her) parents (LWP). With roughly 20 years separating the cohorts, we can

\footnotetext{
${ }^{1}$ For example, if there were 5 million households and 20 million individuals aged 20-25 years in 2001, then the expected number of households as a share of the population for this age group is assumed to be 25 percent over time.

${ }^{2} \mathrm{~A}$ bright spot within the residential investment sector has been multi-family housing starts (construction), which are currently above their pre-recession level. However, multi-family construction makes up a relatively small share of overall residential investment, and the rate of single family housing investment remains subdued.
} 
study the changing pattern of household formation over time. We compare parental co-residence rates for individuals 23-31 years of age within and across cohorts and find that the share of individuals who are LWP declines with age, but that the LWP share is noticeably higher at nearly every age for the 1997 cohort compared to the 1979 cohort. There is also substantial variation in household formation both within and across cohorts based, among other factors, on race and housing costs. For example, a Hispanic youth in the 1997 cohort is roughly 20 percentage points more likely to be LWP than a nonblack/non-Hispanic youth in the 1979 cohort. Similarly, members of the 1997 cohort living in areas that experienced high house price growth are roughly 15 percentage points more likely to be LWP at age 23 than same-age youth from the 1979 cohort who lived in areas that experienced low house price growth. These results suggest that it is important to take into account local economic conditions as well as shifts in the racial composition of the population when projecting the future number of U.S. households.

We further find that there are a number of observable differences across the cohorts in terms of marriage rates, wealth, number of children, and other factors that likely matter for young adults' household formation decisions. Still, members of the 1997 cohort are more likely to be LWP even after controlling for differences in economic conditions and observed characteristics between the two cohorts. This finding suggests that there has been a shift over time in U.S. household formation rates that cannot be easily measured or accounted for by observable factors.

Recent related work on household formation includes Bleemer et al. (2015), Dettling and Hsu (2014), and Paciorek (2013). Bleemer et al. (2015) use individual data from Equifax to examine household formation patterns since 1999. They analyze how debt, jobs, and housing prices contribute to the delay in household formation for 25 year-olds. Relative to our study, however, theirs is limited by a lack of demographic co-variates as well as the fact that they are not certain whether an individual is living with his/her parent(s) or someone else. ${ }^{3}$ In comparison, we consider a broad set of demographic and other factors and show that these have a noticeable impact on household formation. We also compare household formation behavior between two time periods that are 18 years apart.

Dettling and Hsu (2014) also use Equifax data to analyze household formation. This research was completed concurrently with Bleemer et al. (2015), although Dettling and

\footnotetext{
${ }^{3}$ The authors only know whether or not a respondent is living with someone 15-40 years older given the setup of the Equifax data. They argue that this broad definition is useful since they can capture if an individual is living with his/her spouse's parents, a non-parent relative, or a friend's parent.
} 
Hsu (2014) focus on how existing (student and consumer) debt along with debt repayment burdens and, most importantly, debt delinquency impact household formation. Their approach for determining co-residence in the Equifax data is more comprehensive than the one used by Bleemer et al. (2015), but Dettling and Hsu are still limited by a lack of demographic information for their respondents. Dettling and Hsu (2014) also focus on a rather narrow topic related to household formation - the impact of debt and debt delinquency. Our analysis of the factors impacting household formation is much broader. Even though we have a much smaller sample, our analysis provides worthwhile insights for thinking about recent patterns in U.S. household formation.

Another related study, Paciorek (2013), examines household formation or headship rates by age group using data from the Current Population Survey (CPS), the 1980 and 2000 decennial censuses, and the American Community Survey. This analysis is perhaps the most closely related to our own as he considers how both economic and demographic factors impact household formation. Paciorek (2013) also uses data from two distinct time periods for part of the analysis (the 1980 and 2000 Censuses) and observes that rising housing costs explain a large part of the decline in household formation between 1980 and 2000. In addition, he finds that the more recent decline in household formationbetween 2006 and 2010 - is due in part to the rising unemployment rate. Paciorek (2013) further uses his results and data on the share of households by age group to predict U.S. household formation through 2020. A difference between his work and ours is that he focuses on household formation across the full age spectrum, while we provide detailed analysis of the household formation behavior of young adults - the group most likely to cause large swings in aggregate household formation. We also consider changes in the household formation behavior of these younger respondents over time and demonstrate that there has been a recent decline in the U.S. household formation rate even after controlling for changes in individual characteristics and economic conditions.

The remainder of this policy brief proceeds as follows: Section 2 describes the data and our methodology for determining whether or not an individual lives with at least one of his/her parents. Section 3 describes our results, and section 4 concludes.

\section{Data and Methodology}

The data used in this paper come from two cohorts of the National Longitudinal Survey of Youth (NLSY) - a survey conducted by the U.S Bureau of Labor Statistics (BLS). The 
first cohort (the 1979 cohort) is a nationally representative sample of 12,686 youth who were 14-22 years-old in 1979. These individuals were born between 1957 and 1965 and by the early-to-mid 1980s most were around 25 years-old - a time when many transition to living on their own. The second cohort (the 1997 cohort) is a nationally representative sample of about 9,000 youth who were 12-16 years-old as of December 31, 1996. Born between 1980 and 1984, these individuals were around 25 years-old in the mid-to-late 2000s.

Members of the 1979 cohort were surveyed annually between 1979 and 1993 and have been surveyed biennially since 1994. The most recently available data are for 2012, when the respondents were between 47 and 55 years-old. Those in the 1997 youth cohort have been surveyed annually since 1997, and the most recent available data are for 2011 when the respondents were 27-31 years-old.

These two NLSY surveys - often referred to as the NLSY79 and the NLSY97 - contain detailed information on the respondents' education, employment history, and income, along with other demographic and financial information. In addition, both NLSY surveys contain a so-called household roster, which tracks up to 17 individuals living in the same residence as the respondent, and notes their relationship to the youth. We use these data to determine whether the youth respondent is living with his/her parents as opposed to living independently. We define a youth as "living with parents" (LWP) if at least one biological, adoptive, or step-parent is present in the youth's household in a given interview round.

We analyze how the rate of LWP fluctuates based on observable factors both within and across cohorts by using detailed demographic data from the NLSY surveys. In addition, we obtained geographic data for each youth respondent, including the state in which they live during each survey period. ${ }^{4}$ These geographic identifiers allow us to incorporate additional geographically based economic information in our analysis - data such as local economic conditions (unemployment rates) and housing costs - that are not otherwise available in the survey data.

Our measure of housing costs, which we discuss in more detail in the appendix, is based on median home prices relative to median income for young adults in a given state. Figure 3 shows that there is substantial variation in our housing cost measure across states as well as over time. Besides detailing how we construct housing costs, the appendix also documents the additional data sources that we use for our analysis.

\footnotetext{
${ }^{4}$ These data were obtained under a restricted data access contract with the BLS designed to protect the identities of the respondents.
} 
The 1979 and 1997 NLSY cohorts are useful for studying changes in U.S. household formation over time since the surveys cover two representative groups of youth entering adulthood over a twenty-year period, and contain detailed information on the youth respondents' living situations. Granted, youth in the two cohorts enter young adulthood at different points in the business and housing cycles, but we can condition our results on these potential differences when we analyze the factors that impact whether or not they choose to be LWP.

\section{Results}

\subsection{Results Conditional on Age}

The first set of results compares LWP by age and cohort. In particular, we focus on the share of youth respondents who are LWP between the ages of 14 and 31 yearsthe common observed ages across the two cohorts. This approach enables us to easily compare and analyze differences in household formation within and across cohorts by age. $^{5}$

Figure 4 shows the share of youth LWP in the 1979 cohort (solid line) compared with the share in the 1997 cohort (dashed line). Not surprisingly, the share of youth LWP is quite high when the respondents are young but declines somewhat rapidly after age 18, when they become legal adults and potentially move out of their parents' homes to attend college or to start a career. The proportion of youth LWP is noticeably higher for the 1997 cohort than the 1979 cohort starting after about age 16. The gap in the shares of those who LWP is the largest when youth are in their early 20 s and closes a bit over time. Overall, the results suggest that the household formation rate for young adults has declined over time across the age distribution.

A similar pattern emerges when we compare the share of respondents LWP by state across the two cohorts (see Figure 5). ${ }^{6}$ The darker shaded states have a relatively larger portion of respondents LWP than other states, and the figure shows that there are more darkly shaded states for the 1997 cohort compared to the 1979 cohort. This is especially true in California, the Northeast, and the mid-Atlantic areas where higher housing costs

\footnotetext{
${ }^{5}$ We use the terms "LWP" and "household formation" interchangeably - a higher share of LWP corresponds to lower household formation rates.

${ }^{6}$ We measure the share of respondents LWP by state by averaging the shares for respondents who are 23-31 years-old who LWP in that state. Respondents in the 1979 cohort are $23-31$ years-old in 1980-1994, while those in the 1997 cohort reach the ages of 23-31 years between 2002 and 2011.
} 
and other factors in recent years likely made it more difficult for young adults to live independently compared to the 1980s.

We also examine how household formation varies based on demographic factors both within and across cohorts. Figure 6 compares the share of youth LWP for three racial groups: non-black/non-Hispanic, blacks, and Hispanics. The share of black youth LWP is substantially lower at young ages in both cohorts, perhaps due in part to the high incarceration rate of black males. After age 18 or 19, however, blacks and Hispanics are more likely to be LWP than non-black/non-Hispanic youth.

Figure 7 shows that there have also been shifts by race in the share of respondents LWP over time. In the 1997 cohort, non-black/non-Hispanic and Hispanic youths, regardless of age, are more likely to be LWP relative to their 1979 counterparts, while the rate of LWP for blacks is unchanged. In addition, the differences across cohorts in the share of respondents LWP by race are economically meaningful. For example, a Hispanic youth in 1997 is roughly 20 percentage points more likely to be LWP than a non-black/non-Hispanic youth in 1979 .

Overall, these results demonstrate that there is important variation in household formation by race both within a given cohort and over time - a result which suggests that failing to account for demographic shifts in the racial composition of the U.S. population could lead to inaccurate predictions about the future number of U.S. households. Such demographic changes, however, tend to be fairly slow moving so it is unlikely that these shifts could fully account for the sudden decrease in the U.S. household formation rate starting around 2006.

Comparing the fraction of youth LWP by census region across the two cohorts (not graphed) suggests that location may also matter for household formation. Indeed, the number of those youth LWP is higher in the West for the 1997 cohort compared with the 1979 cohort and is somewhat higher in the South and Northeast, while the share of respondents LWP is about the same over time in the North Central (Midwest) region. This pattern of results further suggests that housing costs, which tend to be higher in the Northeast and West, could play a role in the youth respondents' decision whether or not to be LWP.

Figure 8 examines the impact of housing costs on household formation more closely. In particular, we divide each cohort into three groups (terciles) based on the distribution of housing costs (house prices relative to income) in the state in which the youth respondent 
lives in a given year. ${ }^{7}$ Respondents in the "top" group are those living in areas where housing costs are in the top third of the distribution, respondents in the "middle" are those living in places where housing costs are in the middle third of the distribution, and respondents in the "bottom" group live in areas with the lowest housing costs.

The figure shows that the share of respondents LWP generally rose with housing costs for the 1979 cohort. In addition, youth living in high housing cost areas in the 1997 cohort were substantially more likely to be LWP than respondents in either the middle or bottom tercile of the housing cost distribution (with limited differences between the middle and bottom terciles). Across cohorts, the 1997 youth who lived in areas with high housing costs were more likely to be LWP at nearly every age compared to members of the 1979 cohort who also experienced high housing costs. The same is true, however, for respondents who were living in low housing cost areas. Still, Figure 9 shows that housing costs have an overall meaningful effect on LWP. For example, members of the 1997 cohort living in high housing cost areas (top) were roughly 15 percentage points more likely at age 23 to be LWP than members of the 1979 cohort who were the same age but living in areas with low housing costs (bottom).

Finally, as noted earlier, household formation occurs when individuals move out of their current residence and form a residence of their own - a process that can be reversed by individuals moving back in with their parents or combining their household with others due to, for instance, marriage. Since we observe the same respondents in consecutive waves of each NLSY survey we can track the respondents' transitions to and from LWP starting at age 18. Figure 10 shows the share of respondents, by age, who transition away from LWP (left panel) and the share who transition back to LWP (right panel). ${ }^{8}$ Members of the 1997 cohort were much more likely to move back in with their parentsespecially once they are 20 years of age or older-than members of the 1979 cohort. Members of the 1997 cohort also left home somewhat later than members of the 1979 cohort. These differences in transition rates and patterns across cohorts could reflect the different economic conditions faced by the respondents when they were deciding about their living situations as young adults. Indeed, these findings are consistent with recent anecdotal evidence suggesting that the rate of young adults moving back to live with their parents has increased following the Great Recession. Young adults are also said to be waiting longer to move out of their parents' homes in recent years.

\footnotetext{
${ }^{7}$ See the appendix for a detailed definition of our measure of housing costs.

${ }^{8} \mathrm{~A}$ respondent "moves out" if he/she lives without a parent at age $X$ but is LWP at age $X-1$. In contrast, a respondent "moves in" if he/she is LWP at age $X$ but lives without a parent at age $X-1$.
} 


\subsection{Regression Results}

In this section, we analyze who is LWP both within and across cohorts using a linear probability model (OLS). ${ }^{9}$ This approach allows us to analyze patterns of household formation conditional on factors such as age, marital status, and economic conditions that are likely to affect whether or not a respondent is LWP. The dependant variable in all of our estimations is an indicator that takes a value of 1 if the respondent is LWP in a given year and is zero otherwise. The main controls are the respondent's age, which we allow to enter nonlinearly by including dummy variables for each age in our sample (23-31), various demographics including race, region of residence, parental education, gender, an indicator for whether or not the respondent is enrolled in school, and an indicator for whether or not the respondent has completed college. ${ }^{10}$ We also include the state-level (annual) unemployment rate when a respondent is a given age, along with our measure of housing costs (discussed earlier) to capture economic conditions that might impact household formation. In particular, respondents are probably more likely to be LWP when employment prospects are limited and/or housing costs are elevated.

\subsubsection{Pooled Cohort Analysis}

Table 1 summarizes the results from regressions that pool respondents from the two cohorts together - an approach that allows us to examine whether there is a so-called cohort (or time) effect on household formation after controlling for observable demographic, financial, and other economic factors. These baseline regressions include respondents who are 23-31 years-old - an age range that focuses on the main formative years for households headed by young adults and avoids, for instance, the potentially confounding effect of respondents moving in and out of their parents' home frequently while they are in college. The results for the full sample of respondents - those 16-31 years of age - are qualitatively similar and are shown in Table A.4 in the appendix.

When conditioning on age only, shown in column (1) of Table 1, we obtain an average gap of 3.8 percentage points across the two cohorts among those who are LWP - an effect that is very precisely estimated. ${ }^{11}$ Including demographic controls, shown in column (2),

\footnotetext{
${ }^{9}$ The results are qualitatively similar if we analyze LWP using a probit model rather than a linear probability model (OLS). We employ the OLS approach for ease of interpreting our findings.

${ }^{10}$ To maximize the number of observations, we include dummy variable indicators for missing values in the set of regressors listed above as needed.

${ }^{11}$ Robust standard errors are clustered at the individual level. Clustering at the state level yields nearly identical results.
} 
has little impact on this average gap. We also find that female respondents are, on average, less likely to be LWP. In addition, respondents who are in school are more likely to live at home, but once they finish college they are more likely to live elsewhere. Hispanics and blacks have a higher likelihood of LWP - similar to the unconditional analysis - as do respondents living in the Northeast and in urban locations. Those respondents with more educated fathers are also less likely to be LWP.

In Table 1, column (3) includes controls for economic conditions - state-level unemployment and state-level housing costs - in addition to the demographic controls. For easier interpretation, these variables have been standardized to have a mean of zero and a standard deviation of one. Adverse economic conditions, as captured by higher rates of unemployment, increase the likelihood that a young adult will be LWP - a one standard deviation higher unemployment rate increases the likelihood of LWP by 1.4 percentage points. Higher housing costs also increase the likelihood of LWP — one standard deviation of higher housing costs relative to income increases by 3 percentage points the likelihood that someone will be LWP. More importantly, including these controls reduces the average gap in LWP across the two cohorts by nearly 45 percent. In sum, controlling for economic conditions substantially, but not completely, reduces the unexplained differences in average household formation rates across cohorts for our survey respondents.

Lastly, the estimates in column (4) examine whether the effect of economic conditions on who is LWP varies by race. In principle, the observed differences in LWP by race could be due to the fact that certain groups live in areas more affected by the business cycle and face less social and/or cultural barriers to be LWP when the economy is bad or housing costs are high. Our results suggest that the fraction of black youth who lives with parents is less responsive to changes in economic conditions (the state unemployment rate rising or housing costs being higher), perhaps because black parents are more likely to be cashconstrained, and are less able to provide for their young adult children. In contrast, the likelihood that Hispanic youth will be LWP during economic downturns is about the same as non-black/non-Hispanics. Hispanics also are more likely than non-black/non-hispanics to live with their parents as housing costs rise relative to income.

\subsubsection{Cohort-by-Cohort Analysis}

Table 2 presents additional results that examine the impact of demographic and economic factors on LWP within each cohort. ${ }^{12}$ This approach allows us to determine whether the

\footnotetext{
${ }^{12}$ We pool all available observations on the youth respondents within a cohort.
} 
effect of a demographic or economic factor on the respondents' likelihood of LWP has changed substantially over time. For example, this method lets us compare whether the effect of housing costs on the likelihood of LWP is larger (or smaller) for the 1997 cohort than for the 1979 cohort. Without loss of generality, we report results based on the specification in Table 1, column (3); again, we focus on individuals who are 23-31 yearsold. Column (1) shows results for the 1979 cohort, column (2) presents results for the 1997 cohort, and the last column ("Difference") indicates whether the estimated effect is statistically different across cohorts at either the 10 percent, 5 percent, or 1 percent level of significance.

Overall, the effect of demographic factors on the probability that someone will be LWP is quite similar across the two cohorts, suggesting that there have been limited shifts in the predictors of household formation over time. The few factors that do have a significantly different impact across cohorts on the likelihood of LWP include being black, living in an urban area, having a college-educated mother, and experiencing high unemployment and housing costs. Most noticeably, we find that while black respondents in the 1997 cohort are more likely to be LWP than non-black/non-Hispanics, the impact of being black on LWP is roughly half as large as it was for the 1979 cohort.

In comparison, economic conditions have a larger effect on the chances of LWP for members of the more recent cohort. Indeed, higher housing costs increase the likelihood of LWP relatively more for the 1997 cohort - when facing a one-standard deviation increase in housing costs (relative to income), respondents in the 1979 (1997) cohort are 1.2 (4.1) percent more likely to be LWP. Similarly, the state-level unemployment rate has little effect on the likelihood that respondents from the 1979 cohort will be LWP, but has a positive and statistically different impact on 1997 cohort members living at home - a finding that suggests the business cycle played a relatively more important role in the household formation decisions of this more recent youth cohort. This result is consistent with the fact that members of the 1997 cohort experienced a very poor job market during the Great Recession - a topic that we shall explore in more detail. ${ }^{13}$

The next set of results compares predictors of LWP across the two cohorts when we split the sample by race. This approach allows us to further examine the role that race plays in predicting household formation patterns over time. Table 3 shows that the impact of demographic and economic factors on the youth who lives at home varies over

\footnotetext{
${ }^{13}$ Additionally, we tried specifications with state fixed effects for both the pooled and separate cohort analysis. While the results were similar for the pooled regressions, in separate regressions there is not enough variation over time within a state to identify the effect of varying housing costs in our data.
} 
time by racial group. Rising housing costs increase the likelihood of LWP for respondents from the 1997 cohort more than for respondents from the 1979 cohort (the differences are statistically significant for Hispanics and non-black/non-Hispanics only).

The results further illustrate that economic conditions, as captured by the statelevel unemployment rates, have a larger effect across racial groups on the likelihood that respondents from the 1997 cohort will be LWP. ${ }^{14}$ In addition, both Hispanic and nonblack/non-Hispanic respondents in the 1997 cohort who live in urban areas are more likely to live with their parents than similar respondents in the 1979 cohort. Black respondents residing in urban areas, however, are much more likely in the 1979 cohort to live at home than those in the 1997 cohort. These findings suggest that whether a respondent resides in an urban or rural location is an important predictor for whether non-black/non-Hispanic and Hispanic respondents live with parents, but is not a predictor for black respondents. The impacts of the region fixed effects on the likelihood that a respondent is LWP, as well as whether someone is enrolled in school, also vary over time by race. Overall, these results support our earlier conclusion that one cannot ignore the racial composition of the U.S. population when analyzing and predicting household formation.

Lastly, we use the time dimension of the 1997 NLSY survey to examine how a respondents' own labor market status impacts whether they live with their parents and whether the effect of labor market conditions on the likelihood of LWP changed during and following the Great Recession. The NLSY contains detailed employment and job information for all respondents in each year - therefore we are able to count the number of weeks each respondent may be out of the labor force in a given year. We define a respondent as experiencing a recent negative employment shock if he/she is out of work for 10 or more weeks in the year prior to the survey year. ${ }^{15}$

Table 4 shows the estimated employment effects by race. Columns (1)-(3) only control for the respondents' labor market status, while columns (4)-(6) test whether there is a differential effect on the chances of LWP for respondents that experienced an adverse employment shock during and after the Great Recession. ${ }^{16}$ We find that, regardless of race, respondents who spent 10 or more weeks out of the labor force in the previous year are more likely to be LWP than those respondents who did not experience such a labor market shock. This effect is smallest for Hispanics and largest for non-black/non-

\footnotetext{
${ }^{14}$ Although the difference is not statistically significant for Hispanics.

${ }^{15}$ The results are similar if we alternatively define the negative employment shock as the respondent having been out of work for one week or more.

${ }^{16}$ We include a dummy variable equal to 1 for the years 2008-2011 and interact it with respondents' employment status in a given year.
} 
Hispanics - perhaps reflecting the fact that non-black/non-Hispanic respondents are less inclined to live with their parents unless faced with a negative shock and/or poor economic prospects. For non-black/non-Hispanic respondents this effect seems to be driven by employment shocks in general and not employment losses associated with the Great Recession starting in 2008. In contrast, the labor market effect on the chances that black respondents live at home is entirely driven by these youths' labor market experiences between 2008 and 2011 [column (5)].

If we eliminate the Great Recession years from our sample (2008 and 2009) and compare the impact of employment shocks in 2010 and 2011 on LWP to the impact of employment shocks prior to 2008, the results are similar but not shown. Therefore there is some limited evidence that employment losses following the Great Recession increase the likelihood of LWP. This finding suggests that if the weak labor market during and following the Great Recession explains some of decline in U.S. household formation, then it was the sheer magnitude of the employment losses during this period that impacted household formation rates and not necessarily a fundamental shift in individuals' household formation behavior.

\section{Conclusion}

In this policy brief we presented evidence documenting the demographic and economic factors that influence the household formation behavior of young adults. We found that the factors one expects would matter for whether or not young adults live with their parents - business cycle conditions, housing costs, and the young adult's age - do indeed play a role. Whether or not an individual is married or enrolled in school also affects the likelihood that he/she lives independently.

We further showed that an individual's race noticeably impacts the likelihood of LWP_-both within cohorts and especially over time. These results could be driven by cultural differences, proxied by race, in attitudes toward young adults who live with parents. For example, within certain communities the choice of a young adult to live at home after finishing high school or college may be widely acceptable, whereas in other communities this preference may be viewed less favorably.

Still, while acknowledging that the racial composition of the U.S. population appears to be important for accurately predicting household formation rates going forward, population demographics are slow to change. Hence, it is unlikely that a shifting racial mix 
in the United States can account for the sizeable decline observed in aggregate household formation rates starting around 2006. Similarly, a decline in marriage rates over time by age (see Figure 11) may slow household formation, but again this demographic trend will not change suddenly. The sheer magnitude of the employment losses during the Great Recession could explain some of the decline in household formation, but even after controlling for state-level unemployment rates (and other factors) we cannot fully account for the cohort-based difference in individuals' likelihood of living independently from their parents.

To a certain degree, young adults seem inherently more likely to live with parents now than in the past. Potential explanations for this phenomenon include smaller family sizes and larger homes over time, which make it easier for young adults to cohabit comfortably with their parents. In addition, young adults' wealth accumulation has also declined over time (see Figure 12), making it more difficult for them to afford to live independently and/or purchase homes. However, it is unlikely that these explanations or any of our observed predictors of who will live at home, or changes in the impact of these factors on the likelihood of LWP over time, can explain the recent abrupt downward shift in the U.S. household formation rate. More work is needed to explore these and other possible explanations for the recent change in household formation behavior in the United States.

\section{References}

Bleemer, Zachary, Meta Brown, Donghoon Lee, and Wilbert van der Klaauw. 2015. "Debt, Jobs, or Housing: What's Keeping Millennials at Home." Staff Report No. 700. New York, NY: Federal Reserve Bank of New York. Available at: http://www.newyorkfed.org/research/ staff_reports/sr700.pdf.

Dettling, Lisa, and Joanne Hsu. 2014. "Returning to the Nest: Debt and Parental Co-Residence Among Young Adults." Finance and Economics Discussion Series 2014-80. Washington, DC: Federal Reserve Board of Governors. Available at: http://www.federalreserve.gov/ econresdata/feds/2014/files/201480pap.pdf.

Paciorek, Andrew. 2013. "The Long and Short of Household Formation." Finance and Economics Discussion Series 2013-26. Washington, DC: Federal Reserve Board of Governors. Available at: http://www.federalreserve.gov/pubs/feds/2013/201326/ 201326pap.pdf. 
Figure 1: Residential Investment and House Prices
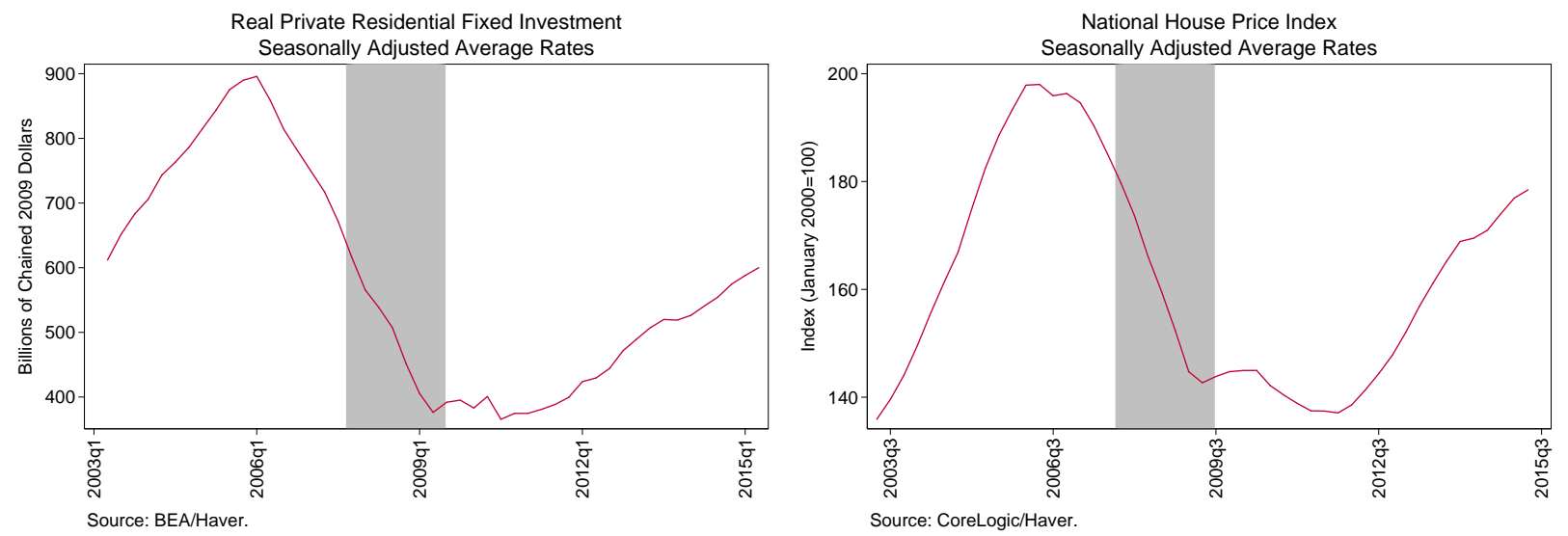

Figure 2: Household Formation Relative to Trend

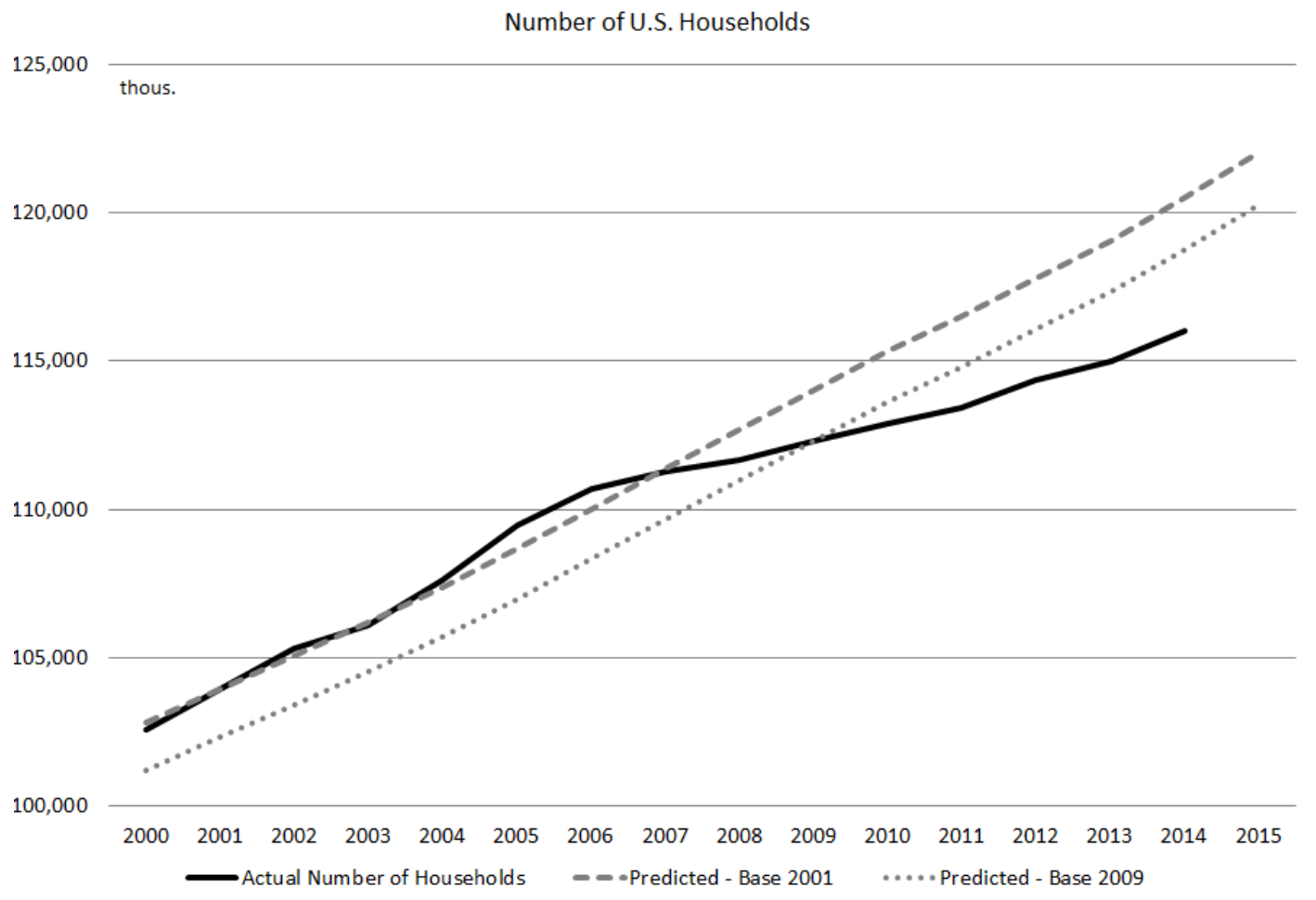

Source: Authors' calculations using Census data. 
Figure 3: Housing Costs by State

1979 Cohort

다

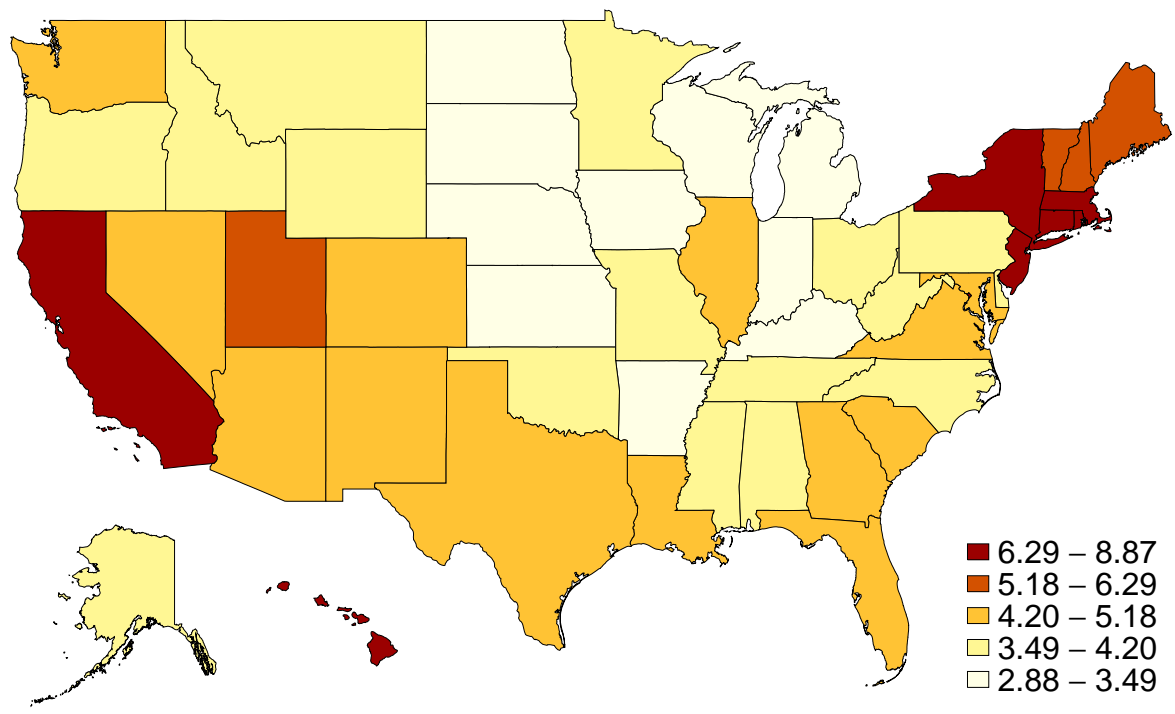

1997 Cohort

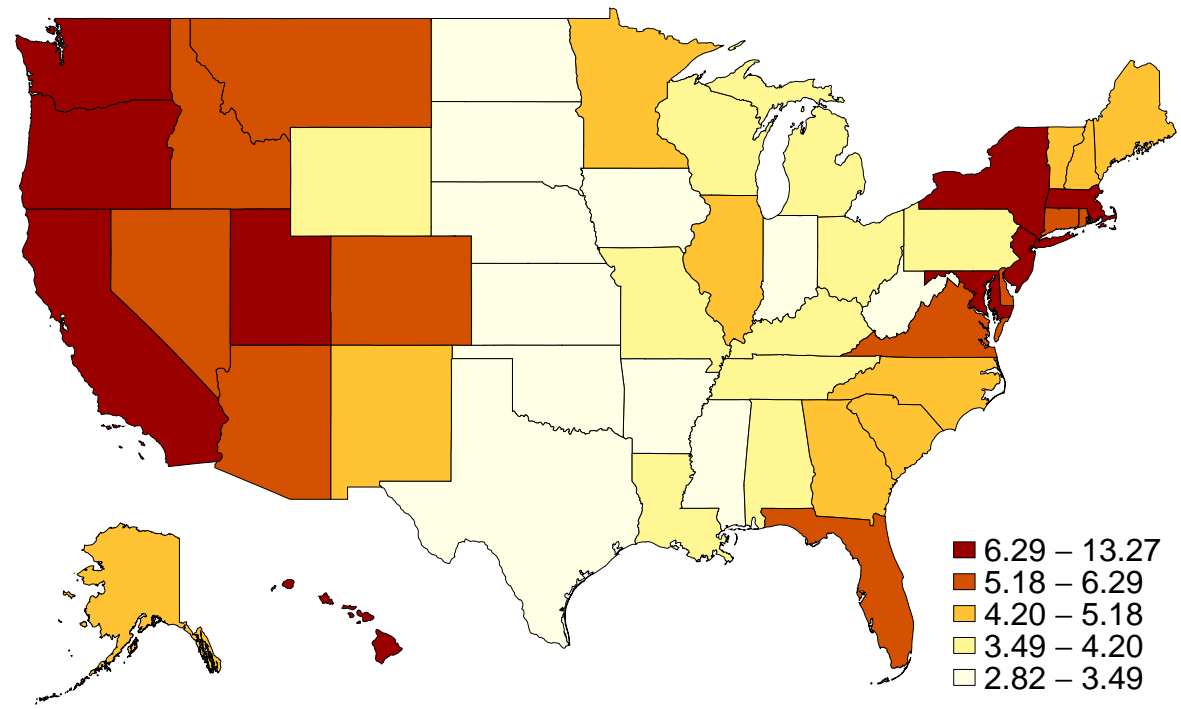

Source: Authors' calculations using NLSY data

Note: Average of state-level house value to income ratios for 23-30 year-old respondents. 
Figure 4: Living with Parents Across the 1979 and 1997 Cohorts: A First Look

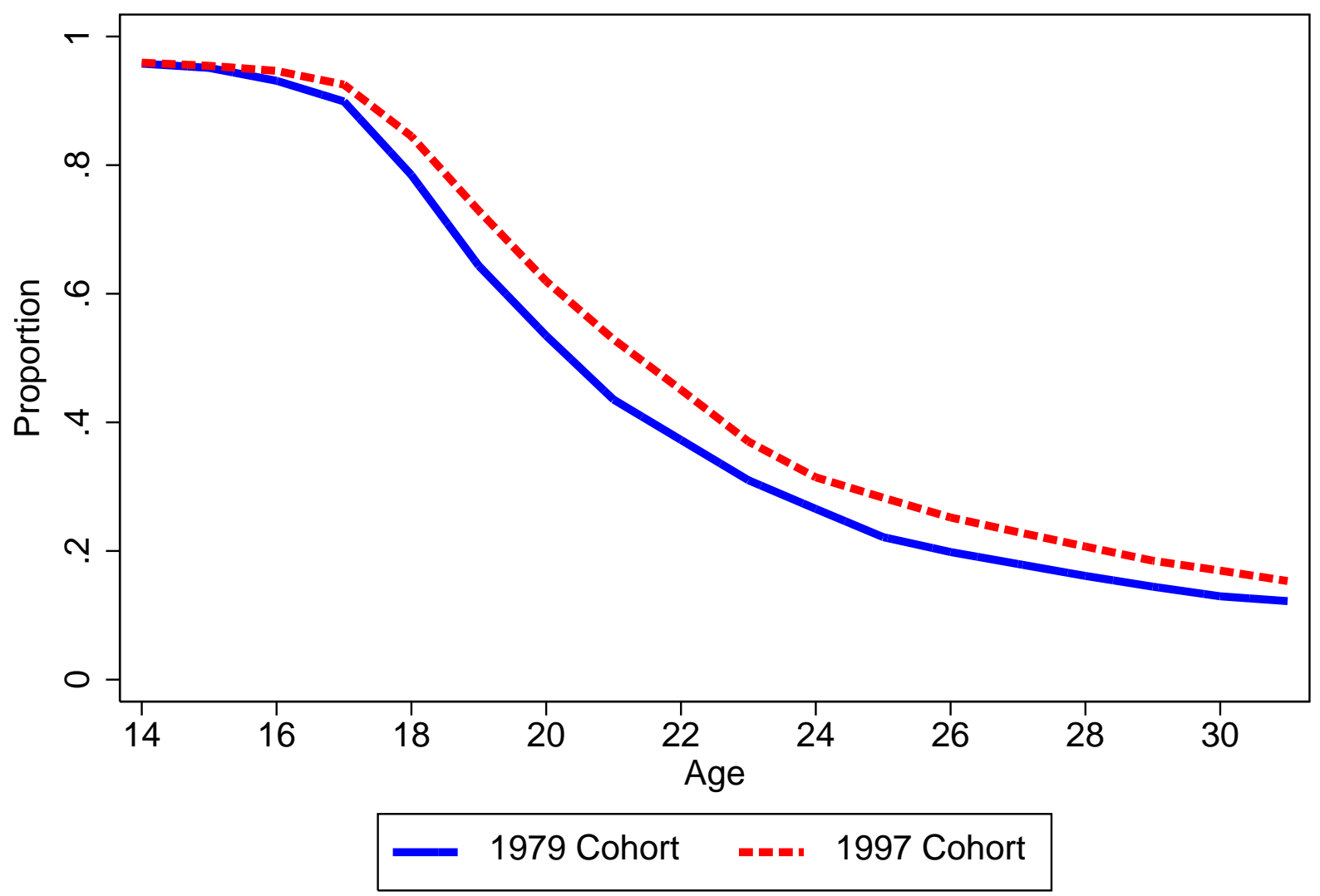

Source: Authors' calculations using NLSY data. 
Figure 5: Living with Parents by State

1979 Cohort

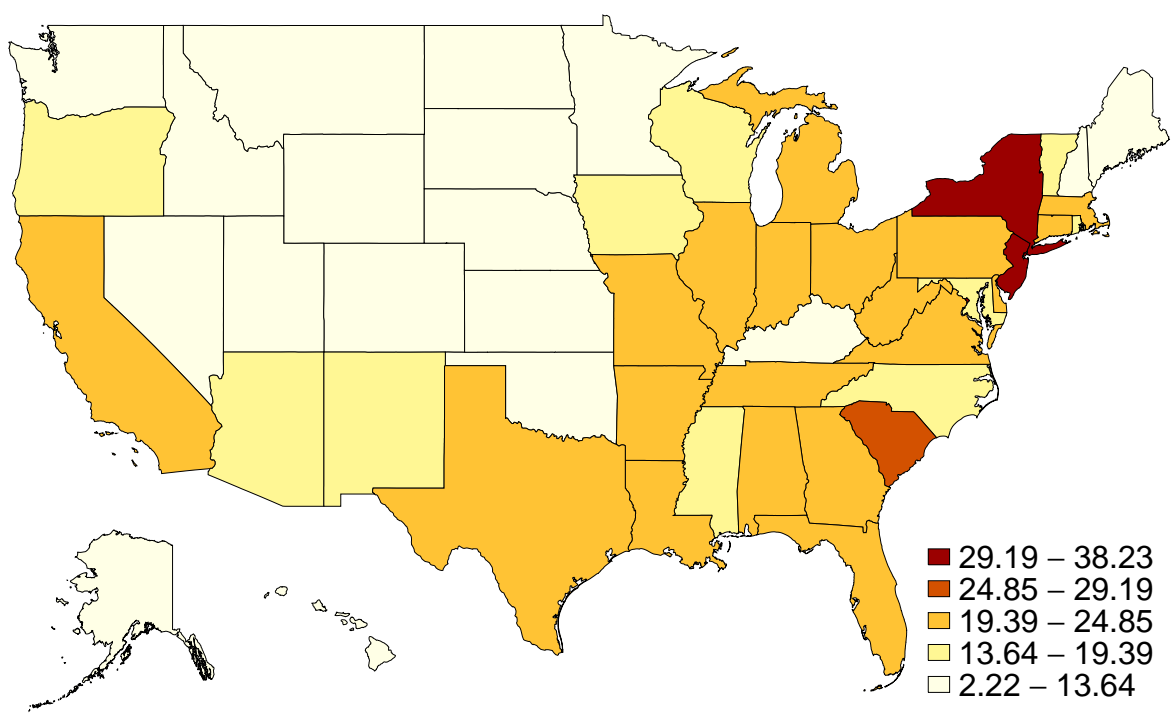

1997 Cohort

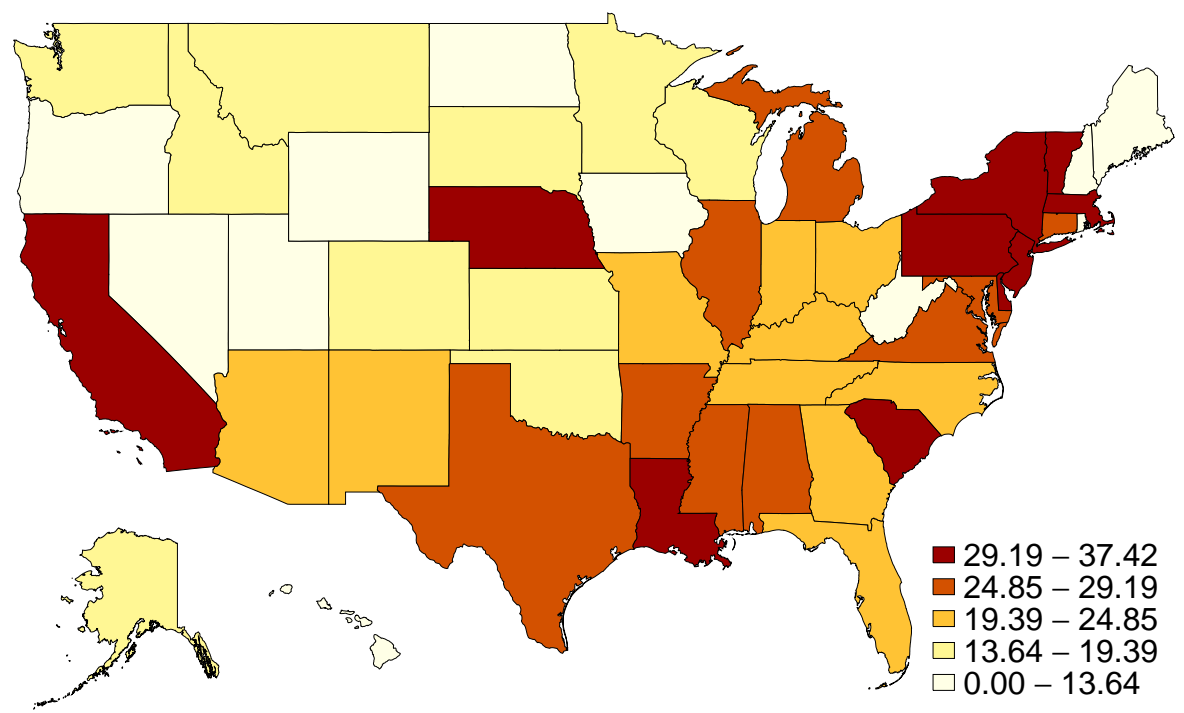

Source: Authors' calculations using NLSY data.

Note: Average percentage of 23-30 year-old respondents living with parents. 
Figure 6: Living with Parents by Race and Age
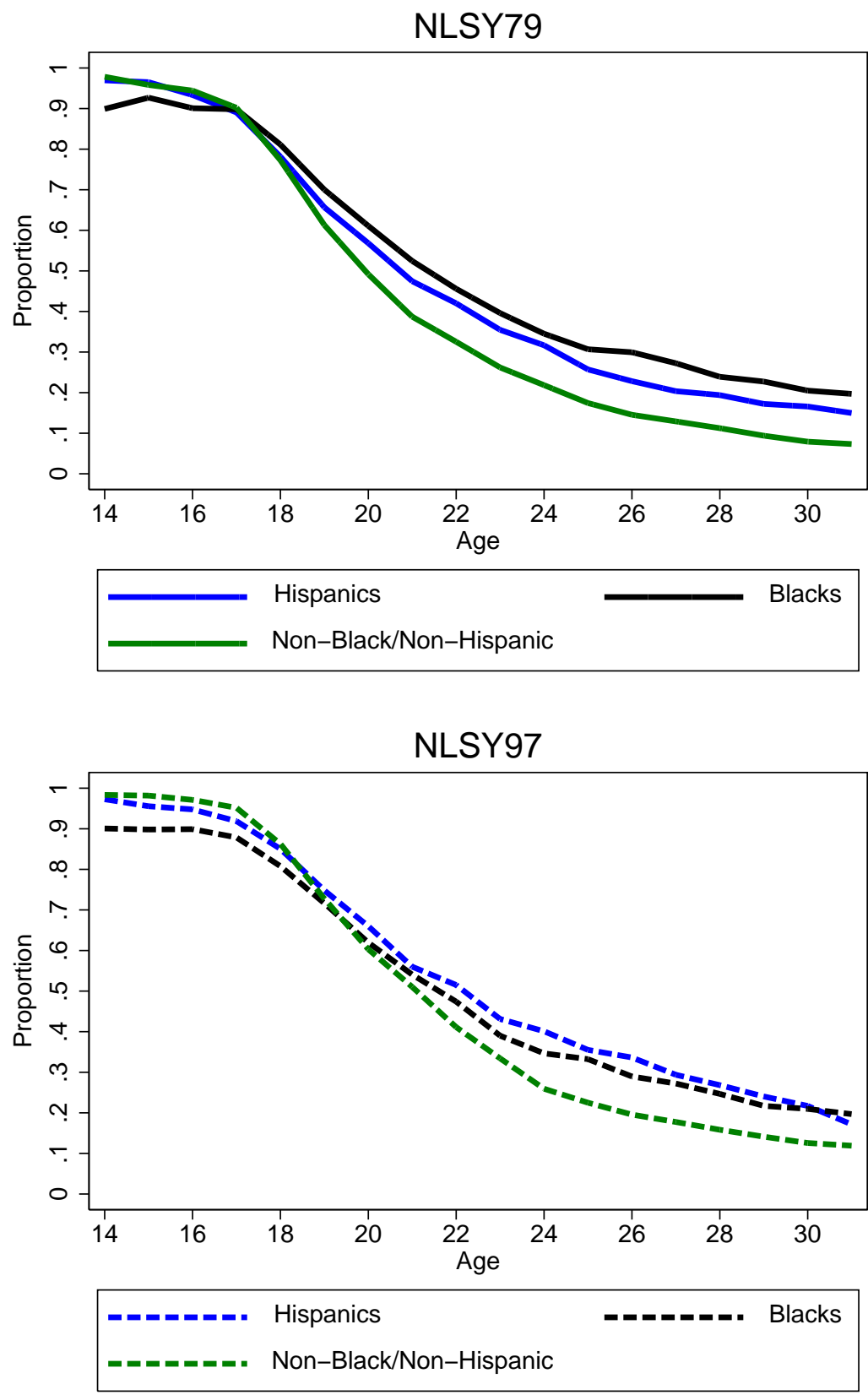

Source: Authors' calculations using NLSY data. 
Figure 7: Living with Parents by Race, Age, and Cohort
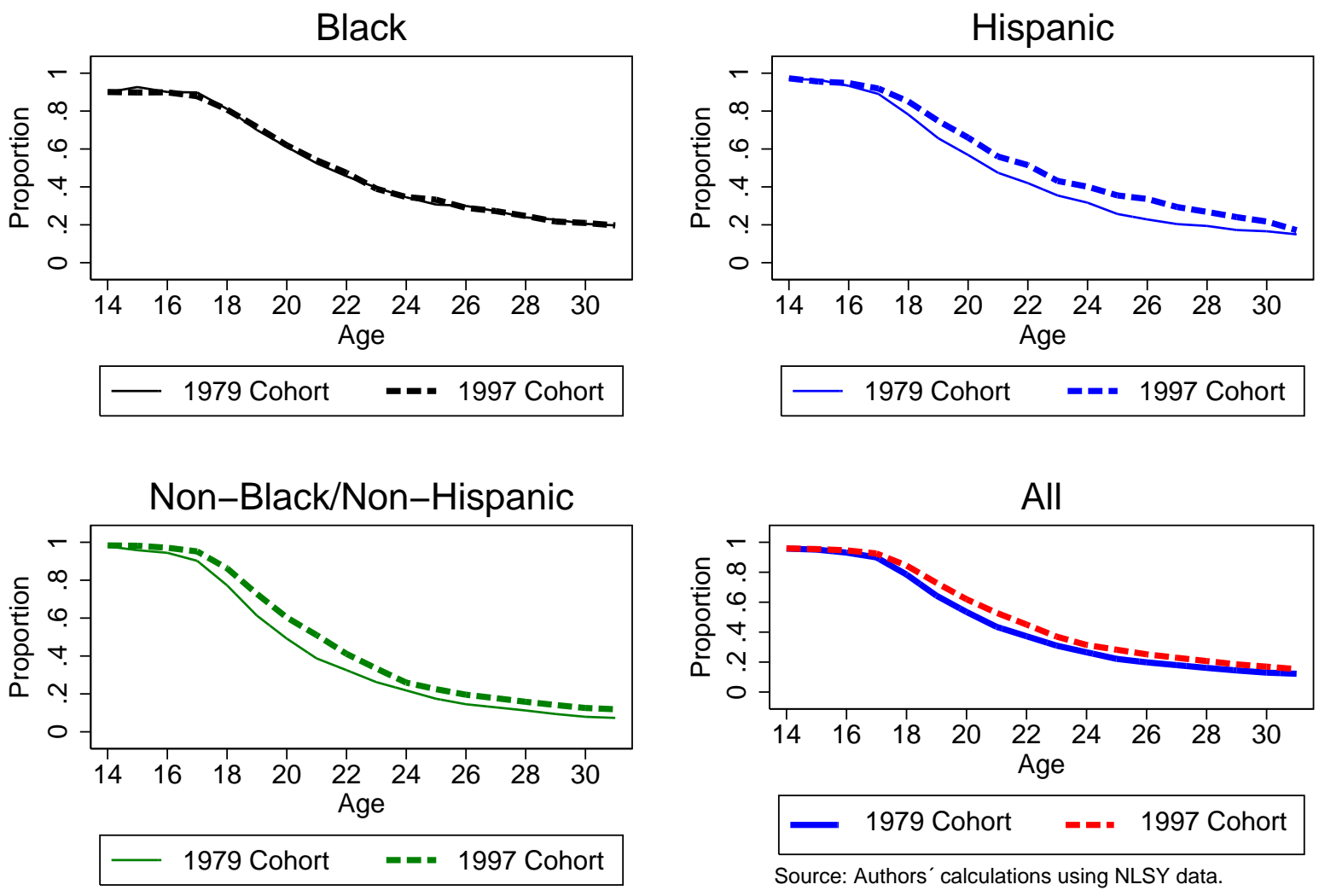

Source: Authors' calculations using NLSY data. 
Figure 8: Living with Parents by Cohort and House-Price Growth
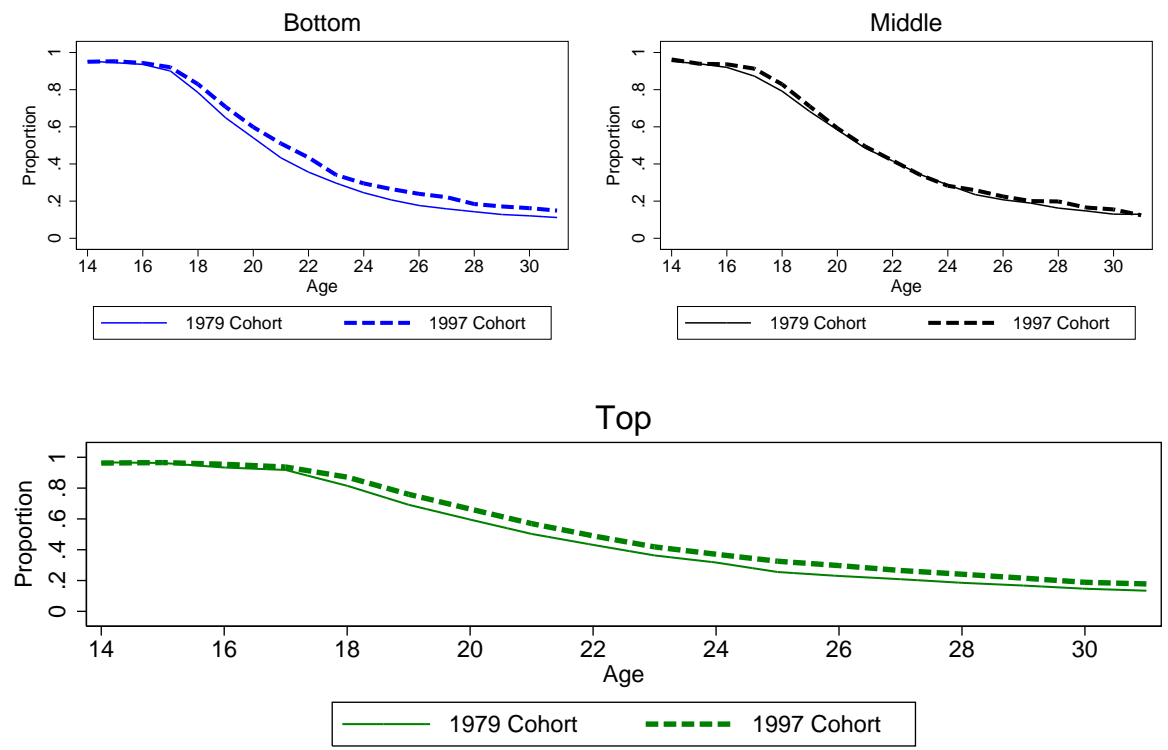

Source: Authors' calculations from NLSY data.

Note: Households divided into terciles based on house-price growth.

Figure 9: Living with Parents by Age, Cohort, and House-Price Growth

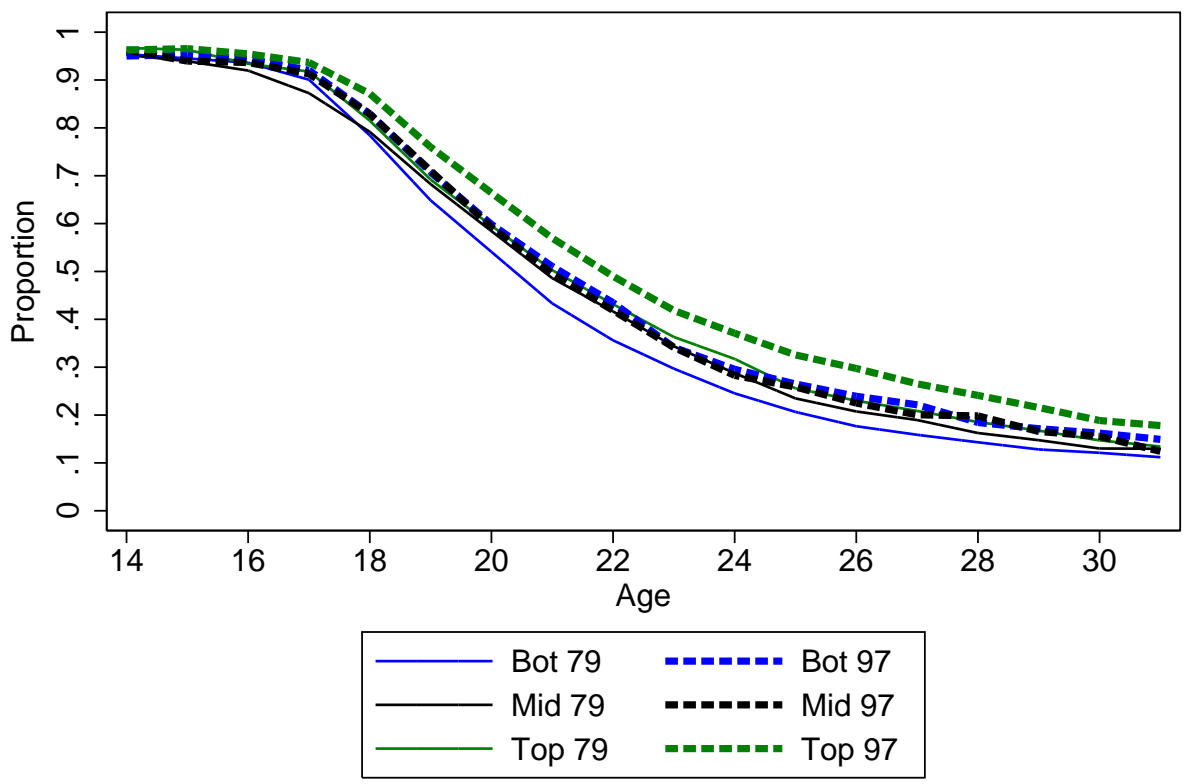

Source: Authors' calculations using NLSY data.

Note: Households divided into terciles based on house-price growth. 
Figure 10: Transitioning from or to Living with Parents by Age
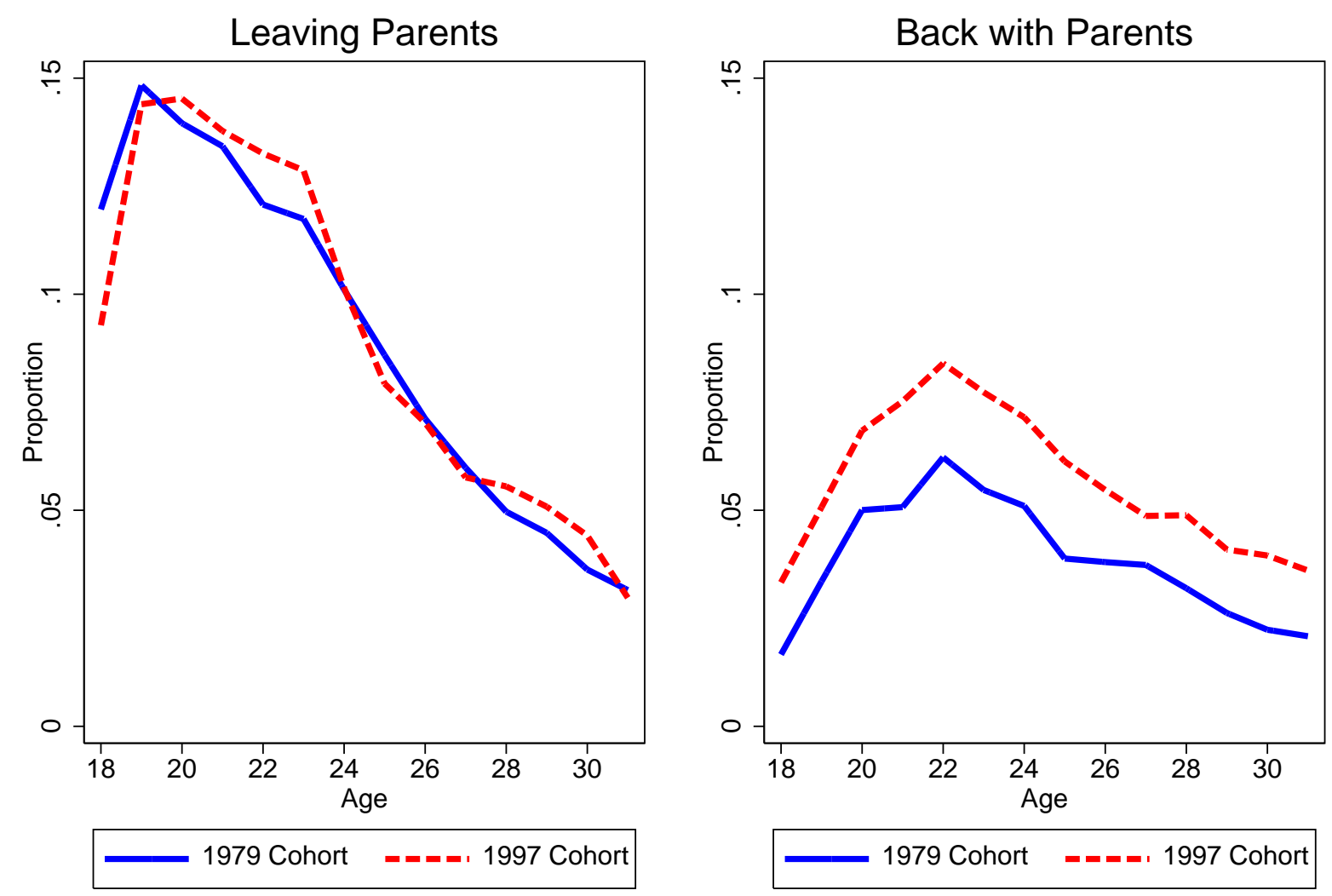

Source: Authors' calculations using NLSY data. 
Figure 11: Differences Across Cohorts: Percent Married by Age

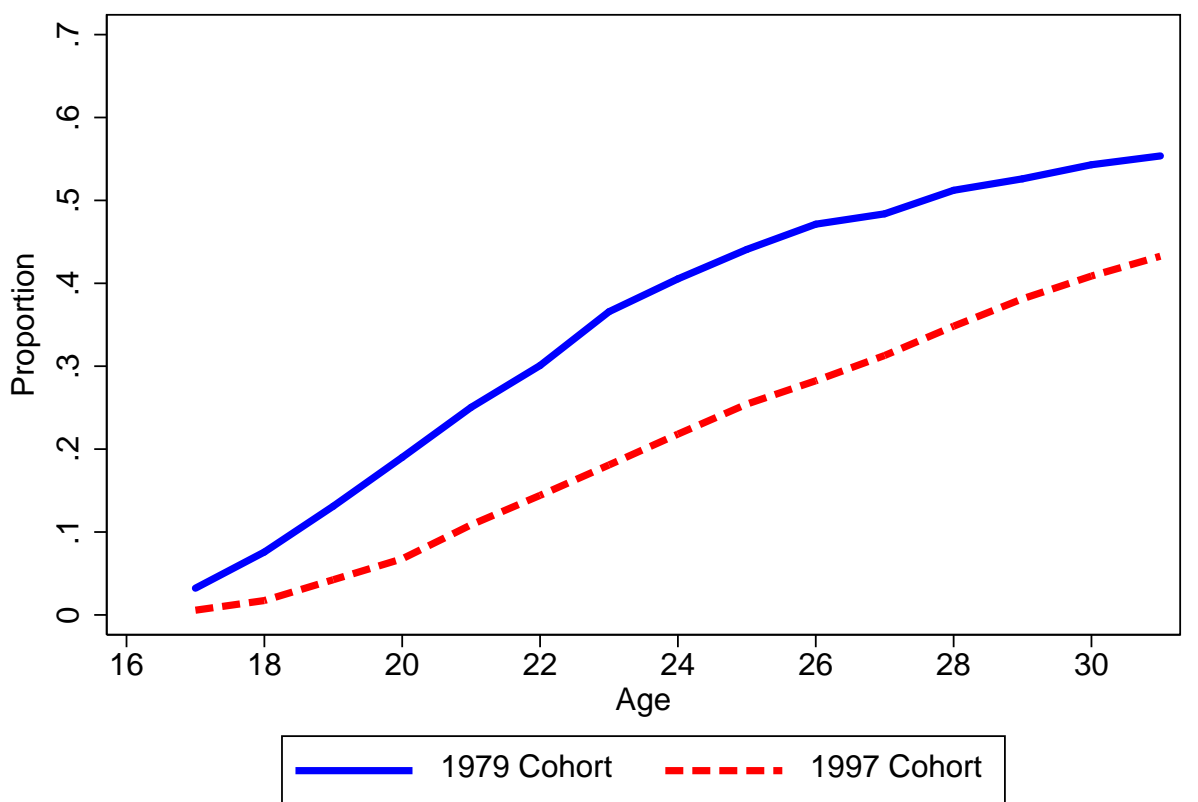

Source: Authors' calculations using NLSY data.

Figure 12: Differences Across Cohorts: Net Worth

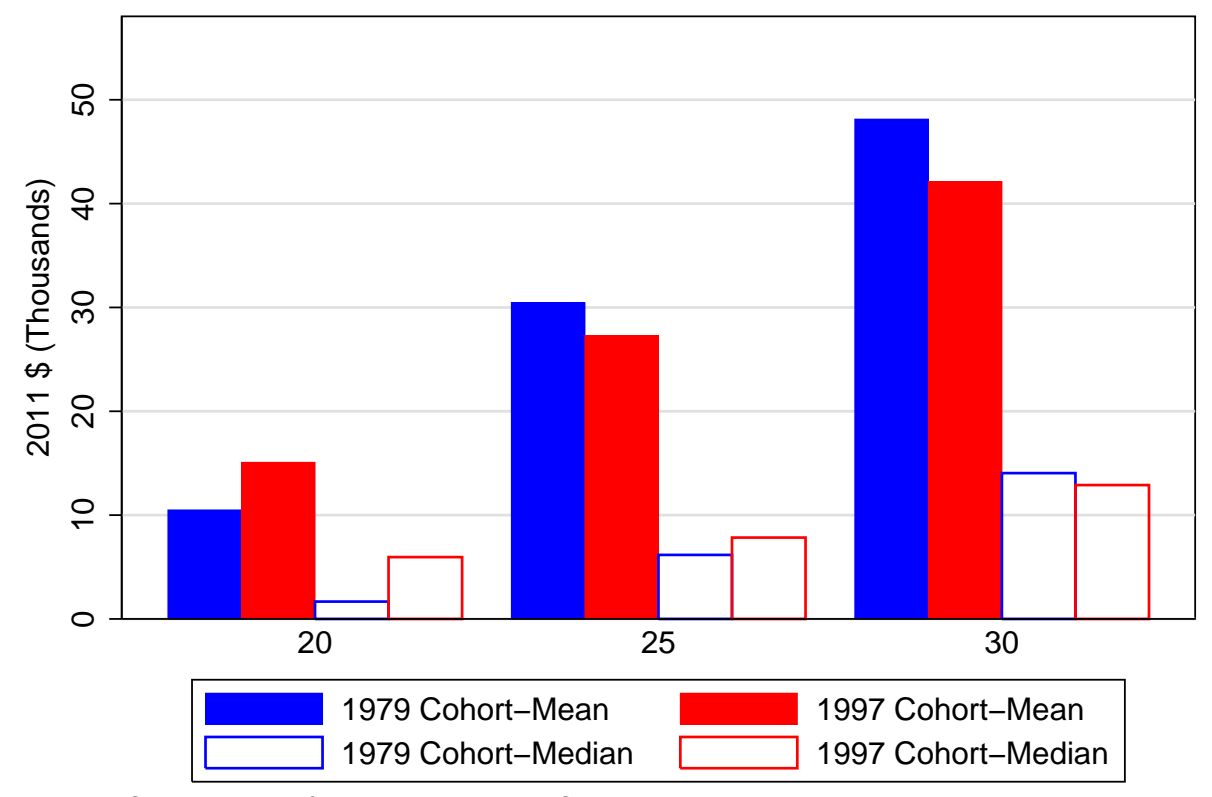

Source: Authors' calculations using NLSY data. Note: Net Worth $=$ Assets - Liabilities 
TABle 1: Living with Parents. Pooled Cohorts

\begin{tabular}{|c|c|c|c|c|}
\hline & (1) & $(2)$ & $(3)$ & $(4)$ \\
\hline 1997 Cohort $^{1}$ & $\begin{array}{c}0.038^{* * *} \\
(0.005)\end{array}$ & $\begin{array}{c}0.036^{* * * *} \\
(0.005)\end{array}$ & $\begin{array}{c}0.020^{* * *} \\
(0.005)\end{array}$ & $\begin{array}{c}0.021^{* * *} \\
(0.005)\end{array}$ \\
\hline Female & & $\begin{array}{c}-0.079 * * * \\
(0.005)\end{array}$ & $\begin{array}{c}-0.080^{* * * *} \\
(0.005)\end{array}$ & $\begin{array}{c}-0.080 * * * \\
(0.005)\end{array}$ \\
\hline Enrolled in School & & $\begin{array}{c}0.034^{* * *} \\
(0.006)\end{array}$ & $\begin{array}{c}0.033^{* * *} \\
(0.006)\end{array}$ & $\begin{array}{c}0.033^{* * *} \\
(0.006)\end{array}$ \\
\hline Has Finished College & & $\begin{array}{c}-0.023^{* * *} \\
(0.006)\end{array}$ & $\begin{array}{c}-0.024^{* * *} \\
(0.006)\end{array}$ & $\begin{array}{c}-0.024^{* * *} \\
(0.006)\end{array}$ \\
\hline Hispanic & & $\begin{array}{c}0.086^{* * *} \\
(0.007)\end{array}$ & $\begin{array}{c}0.079^{* * *} \\
(0.007)\end{array}$ & $\begin{array}{c}0.072^{* * * *} \\
(0.007)\end{array}$ \\
\hline Black & & $\begin{array}{c}0.100^{* * * *} \\
(0.006)\end{array}$ & $\begin{array}{c}0.097^{* * *} \\
(0.006)\end{array}$ & $\begin{array}{c}0.094^{* * *} \\
(0.006)\end{array}$ \\
\hline Northeast & & $\begin{array}{c}0.070^{* * * *} \\
(0.008)\end{array}$ & $\begin{array}{c}0.041^{* * *} \\
(0.009)\end{array}$ & $\begin{array}{c}0.047^{* * *} \\
(0.009)\end{array}$ \\
\hline South & & $\begin{array}{c}0.006 \\
(0.006)\end{array}$ & $\begin{array}{c}0.002 \\
(0.006)\end{array}$ & $\begin{array}{c}0.004 \\
(0.006)\end{array}$ \\
\hline West & & $\begin{array}{l}-0.004 \\
(0.007)\end{array}$ & $\begin{array}{c}-0.055^{* * *} \\
(0.008)\end{array}$ & $\begin{array}{c}-0.053^{* * *} \\
(0.008)\end{array}$ \\
\hline Mom College Graduate & & $\begin{array}{l}-0.003 \\
(0.008)\end{array}$ & $\begin{array}{l}-0.004 \\
(0.008)\end{array}$ & $\begin{array}{c}-0.004 \\
(0.008)\end{array}$ \\
\hline Dad College Graduate & & $\begin{array}{c}-0.031^{* * * *} \\
(0.007)\end{array}$ & $\begin{array}{c}-0.032^{* * *} \\
(0.007)\end{array}$ & $\begin{array}{c}-0.031^{* * *} \\
(0.007)\end{array}$ \\
\hline Urban & & $\begin{array}{c}0.040^{* * *} \\
(0.006)\end{array}$ & $\begin{array}{c}0.036^{* * *} \\
(0.006)\end{array}$ & $\begin{array}{c}0.038^{* * * *} \\
(0.006)\end{array}$ \\
\hline Rural/Urban Unknown & & $\begin{array}{l}-0.002 \\
(0.016)\end{array}$ & $\begin{array}{c}0.002 \\
(0.016)\end{array}$ & $\begin{array}{c}0.005 \\
(0.016)\end{array}$ \\
\hline Unemp (state) & & & $\begin{array}{c}0.014^{* * *} \\
(0.002)\end{array}$ & $\begin{array}{c}0.019^{* * *} \\
(0.002)\end{array}$ \\
\hline Housing Costs (HP/Y, state) & & & $\begin{array}{c}0.030^{* * *} \\
(0.003)\end{array}$ & $\begin{array}{c}0.026^{* * *} \\
(0.004)\end{array}$ \\
\hline Hispanic $\times$ Unemp (state) & & & & $\begin{array}{l}-0.002 \\
(0.004)\end{array}$ \\
\hline Black $\times$ Unemp (state) & & & & $\begin{array}{c}-0.020^{* * *} \\
(0.004)\end{array}$ \\
\hline Hispanic $\times \mathrm{HP} / \mathrm{Y}$ & & & & $\begin{array}{c}0.016^{* * *} \\
(0.006)\end{array}$ \\
\hline Black $\times \mathrm{HP} / \mathrm{Y}$ & & & & $\begin{array}{c}-0.015^{* *} \\
(0.007)\end{array}$ \\
\hline Constant & $\begin{array}{c}0.337^{* * *} \\
(0.006)\end{array}$ & $\begin{array}{c}0.293^{* * *} \\
(0.008)\end{array}$ & $\begin{array}{c}0.331^{* * *} \\
(0.009)\end{array}$ & $\begin{array}{c}0.326^{* * *} \\
(0.009)\end{array}$ \\
\hline Number & 112667 & 112667 & 112667 & 112667 \\
\hline Adj. R-squared. & 0.03 & 0.06 & 0.07 & 0.07 \\
\hline
\end{tabular}

Notes: These results are calculated using a linear probability model. The dependent variable, LWP, is 1 if the respondent reports a parent in the house he/she lives in during the interview. ${ }^{1}$ Indicator variable that takes a value of 1 if the respondent is in the 1997 cohort and 0 if the respondent is in the 1979 cohort. Standard errors clustered at the respondent level. Additional controls include a full set of age dummies from age 24 to age 31 , with age 23 as the base category. ${ }^{*} \mathrm{p}<0.10,{ }^{* *}$ $\mathrm{p}<0.05,{ }^{* * *} \mathrm{p}<0.01$ 
TABLE 2: Living with Parents by Cohort

\begin{tabular}{|c|c|c|c|}
\hline & $\begin{array}{c}\text { NLSY79 } \\
(1)\end{array}$ & $\begin{array}{c}\text { NLSY97 } \\
(2)\end{array}$ & $\begin{array}{c}\text { Difference } \\
(3)\end{array}$ \\
\hline Female & $\begin{array}{c}-0.083^{* * *} \\
(0.006)\end{array}$ & $\begin{array}{c}-0.075^{* * *} \\
(0.007)\end{array}$ & \\
\hline Enrolled in School & $\begin{array}{c}0.045^{* * *} \\
(0.009)\end{array}$ & $\begin{array}{c}0.027^{* * *} \\
(0.008)\end{array}$ & \\
\hline Has Finished College & $\begin{array}{c}-0.022^{* * *} \\
(0.008)\end{array}$ & $\begin{array}{c}-0.031^{* * *} \\
(0.009)\end{array}$ & \\
\hline Hispanic & $\begin{array}{c}0.073^{* * *} \\
(0.009)\end{array}$ & $\begin{array}{c}0.084^{* * *} \\
(0.011)\end{array}$ & \\
\hline Black & $\begin{array}{c}0.128^{* * *} \\
(0.008)\end{array}$ & $\begin{array}{c}0.059^{* * *} \\
(0.010)\end{array}$ & $* * *$ \\
\hline Northeast & $\begin{array}{c}0.045^{* * *} \\
(0.011)\end{array}$ & $\begin{array}{c}0.050^{* * *} \\
(0.013)\end{array}$ & \\
\hline South & $\begin{array}{l}-0.004 \\
(0.008)\end{array}$ & $\begin{array}{c}0.015 \\
(0.010)\end{array}$ & \\
\hline West & $\begin{array}{c}-0.039^{* * *} \\
(0.011)\end{array}$ & $\begin{array}{c}-0.062^{* * *} \\
(0.013)\end{array}$ & \\
\hline Mom College Graduate & $\begin{array}{c}0.014 \\
(0.012)\end{array}$ & $\begin{array}{l}-0.014 \\
(0.011)\end{array}$ & $*$ \\
\hline Dad College Graduate & $\begin{array}{c}-0.031^{\text {**** }} \\
(0.009)\end{array}$ & $\begin{array}{c}-0.032^{* * *} \\
(0.010)\end{array}$ & \\
\hline Urban & $\begin{array}{c}0.036^{* * *} \\
(0.007)\end{array}$ & $\begin{array}{c}0.040^{* * *} \\
(0.009)\end{array}$ & $*$ \\
\hline Unemp (state) & $\begin{array}{c}0.002 \\
(0.002)\end{array}$ & $\begin{array}{c}0.027^{* * *} \\
(0.004)\end{array}$ & $* * *$ \\
\hline Housing Costs (HP/Y, state) & $\begin{array}{c}0.012^{* * *} \\
(0.004)\end{array}$ & $\begin{array}{c}0.041^{* * *} \\
(0.005)\end{array}$ & $* * *$ \\
\hline Constant & $\begin{array}{c}0.315^{* * *} \\
(0.012) \\
\end{array}$ & $\begin{array}{c}0.371^{* * *} \\
(0.012)\end{array}$ & $* * *$ \\
\hline Number & 62354 & 50313 & \\
\hline Adj. R-squared. & 0.07 & 0.05 & \\
\hline
\end{tabular}

Notes: These results are calculated using a linear probability model. The dependent variable, LWP, is 1 if the respondent reports a parent in the house he/she lives in during the interview. Standard errors clustered at the respondent level. Additional controls include a full set of age dummies from age 24 to age 31, with age 23 as the base category. We can reject the null that the age dummies are the same with a $\mathrm{p}<0.05$ or better, except for ages 29 and $30 .{ }^{*} \mathrm{p}<0.10,{ }^{* *} \mathrm{p}<0.05,{ }^{* * *} \mathrm{p}<0.01$ 
TABLE 3: Living with Parents by Cohort and Race

\begin{tabular}{|c|c|c|c|c|c|c|}
\hline & \multicolumn{2}{|c|}{ Hispanics } & \multicolumn{2}{|c|}{ Blacks } & \multicolumn{2}{|c|}{ Non-Black/Non-Hispanic } \\
\hline & $\begin{array}{c}79 \text { Cohort } \\
\text { (1) }\end{array}$ & $\begin{array}{c}97 \text { Cohort } \\
(2)\end{array}$ & $\begin{array}{c}79 \text { Cohort } \\
\text { (3) }\end{array}$ & $\begin{array}{c}97 \text { Cohort } \\
\text { (4) }\end{array}$ & $\begin{array}{c}79 \text { Cohort } \\
(5)\end{array}$ & $\begin{array}{c}97 \text { Cohort } \\
(6)\end{array}$ \\
\hline Female & $\begin{array}{c}-0.097 * * * \\
(0.008)\end{array}$ & $\begin{array}{c}-0.066^{* * *} \\
(0.009)\end{array}$ & $\begin{array}{c}-0.095^{* * *} \\
(0.007)\end{array}$ & $\begin{array}{c}-0.081^{* * *} \\
(0.008)\end{array}$ & $\begin{array}{c}-0.072^{* * *} \\
(0.004)\end{array}$ & $\begin{array}{c}-0.074^{* * *} \\
(0.005)\end{array}$ \\
\hline Enrolled in School & $\begin{array}{c}0.109^{* * *} \\
(0.016)\end{array}$ & $\begin{array}{c}0.032^{* *} \\
(0.013)\end{array}$ & $\begin{array}{l}-0.014 \\
(0.016)\end{array}$ & $\begin{array}{c}0.008 \\
(0.011)\end{array}$ & $\begin{array}{c}0.049^{* * *} \\
(0.008)\end{array}$ & $\begin{array}{c}0.036^{* * *} \\
(0.007)\end{array}$ \\
\hline Has Finished College & $\begin{array}{l}-0.013 \\
(0.016)\end{array}$ & $\begin{array}{c}0.020 \\
(0.015)\end{array}$ & $\begin{array}{c}-0.036^{* * *} \\
(0.012)\end{array}$ & $\begin{array}{c}-0.042^{* * *} \\
(0.012)\end{array}$ & $\begin{array}{c}-0.018^{* * *} \\
(0.005)\end{array}$ & $\begin{array}{c}-0.037^{* * *} \\
(0.006)\end{array}$ \\
\hline Northeast & $\begin{array}{c}0.094^{* * *} \\
(0.018)\end{array}$ & $\begin{array}{l}-0.011 \\
(0.020)\end{array}$ & $\begin{array}{c}0.011 \\
(0.014)\end{array}$ & $\begin{array}{c}0.075^{* * *} \\
(0.015)\end{array}$ & $\begin{array}{c}0.046^{* * *} \\
(0.006)\end{array}$ & $\begin{array}{c}0.066^{* * *} \\
(0.009)\end{array}$ \\
\hline South & $\begin{array}{l}0.030^{*} \\
(0.016)\end{array}$ & $\begin{array}{c}0.013 \\
(0.017)\end{array}$ & $\begin{array}{l}-0.005 \\
(0.009)\end{array}$ & $\begin{array}{c}0.041^{* * *} * \\
(0.011)\end{array}$ & $\begin{array}{c}-0.013^{* * *} \\
(0.005)\end{array}$ & $\begin{array}{l}-0.002 \\
(0.007)\end{array}$ \\
\hline West & $\begin{array}{c}0.008 \\
(0.017)\end{array}$ & $\begin{array}{c}-0.065 * * * \\
(0.019)\end{array}$ & $\begin{array}{c}-0.161^{* * *} \\
(0.019)\end{array}$ & $\begin{array}{c}-0.115^{* * *} \\
(0.021)\end{array}$ & $\begin{array}{c}-0.027^{* * *} \\
(0.007)\end{array}$ & $\begin{array}{c}-0.059^{* * *} \\
(0.009)\end{array}$ \\
\hline Mom College Graduate & $\begin{array}{c}0.002 \\
(0.025)\end{array}$ & $\begin{array}{c}0.003 \\
(0.019)\end{array}$ & $\begin{array}{c}0.023 \\
(0.018)\end{array}$ & $\begin{array}{c}-0.032^{* *} \\
(0.014)\end{array}$ & $\begin{array}{l}0.012^{*} \\
(0.007)\end{array}$ & $\begin{array}{l}-0.010 \\
(0.007)\end{array}$ \\
\hline Dad College Graduate & $\begin{array}{c}-0.065^{* * *} \\
(0.019)\end{array}$ & $\begin{array}{c}-0.041^{* *} \\
(0.018)\end{array}$ & $\begin{array}{l}-0.013 \\
(0.017)\end{array}$ & $\begin{array}{c}0.009 \\
(0.015)\end{array}$ & $\begin{array}{c}-0.028^{* * *} \\
(0.005)\end{array}$ & $\begin{array}{c}-0.040^{* * *} \\
(0.007)\end{array}$ \\
\hline Urban & $\begin{array}{c}0.036^{* *} \\
(0.015)\end{array}$ & $\begin{array}{c}0.091^{* * *} \\
(0.016)\end{array}$ & $\begin{array}{c}0.051^{* * *} \\
(0.009)\end{array}$ & $\begin{array}{l}-0.016 \\
(0.011)\end{array}$ & $\begin{array}{c}0.029^{* * *} \\
(0.004)\end{array}$ & $\begin{array}{c}0.058^{* * *} \\
(0.006)\end{array}$ \\
\hline Unemp (state) & $\begin{array}{c}0.006 \\
(0.004)\end{array}$ & $\begin{array}{c}0.020^{* * *} \\
(0.006)\end{array}$ & $\begin{array}{l}-0.004 \\
(0.004)\end{array}$ & $\begin{array}{c}0.016^{* * *} \\
(0.005)\end{array}$ & $\begin{array}{c}0.005^{* * *} \\
(0.002)\end{array}$ & $\begin{array}{c}0.034^{* * *} \\
(0.003)\end{array}$ \\
\hline Housing Costs (HP/Y, state) & $\begin{array}{c}0.012^{* * *} \\
(0.004)\end{array}$ & $\begin{array}{c}0.054^{* * *} \\
(0.005)\end{array}$ & $\begin{array}{c}0.031^{* * *} \\
(0.006)\end{array}$ & $\begin{array}{c}0.044^{* * *} \\
(0.007)\end{array}$ & $\begin{array}{c}0.010^{* * *} \\
(0.003)\end{array}$ & $\begin{array}{c}0.029^{* * *} \\
(0.004)\end{array}$ \\
\hline Constant & $\begin{array}{c}0.349^{* * *} \\
(0.027)\end{array}$ & $\begin{array}{c}0.385^{* * *} \\
(0.024)\end{array}$ & $\begin{array}{c}0.463^{* * *} \\
(0.020)\end{array}$ & $\begin{array}{c}0.442^{* * *} \\
(0.018)\end{array}$ & $\begin{array}{c}0.310^{* * *} \\
(0.009)\end{array}$ & $\begin{array}{c}0.378^{* * *} \\
(0.009)\end{array}$ \\
\hline Number & 11123 & 10880 & 16619 & 13872 & 34612 & 25561 \\
\hline Adj. R-squared. & 0.05 & 0.04 & 0.04 & 0.03 & 0.05 & 0.05 \\
\hline
\end{tabular}

Notes: These results are calculated using a linear probability model. The dependent variable, LWP, is 1 if the respondent reports a parent in the house he/she lives in during the interview. Standard errors clustered at the respondent level. Additional controls include a full set of age dummies from age 24 to age 31, with age 23 as the base category. ${ }^{*} \mathrm{p}<0.10,{ }^{* *} \mathrm{p}<0.05,{ }^{* * *} \mathrm{p}<0.01$. 
TABle 4: Living with Parents: 1997 Cohort by Race

\begin{tabular}{|c|c|c|c|c|c|c|}
\hline & $\begin{array}{c}\text { Hispanic } \\
(1) \\
\end{array}$ & $\begin{array}{c}\text { Black } \\
(2) \\
\end{array}$ & $\begin{array}{c}\text { Non-Black/ } \\
\text { Non-Hispanic } \\
(3) \\
\end{array}$ & $\begin{array}{c}\text { Hispanic } \\
(4) \\
\end{array}$ & $\begin{array}{c}\text { Black } \\
(5) \\
\end{array}$ & $\begin{array}{c}\text { Non-Black/ } \\
\text { Non-Hispanic } \\
(6)\end{array}$ \\
\hline Female & $\begin{array}{c}-0.069^{* * *} \\
(0.018)\end{array}$ & $\begin{array}{c}-0.082^{* * *} \\
(0.016)\end{array}$ & $\begin{array}{c}-0.079^{* * *} \\
(0.009)\end{array}$ & $\begin{array}{c}-0.069^{* * *} \\
(0.018)\end{array}$ & $\begin{array}{c}-0.082^{* * *} \\
(0.016)\end{array}$ & $\begin{array}{c}-0.079^{* * *} * \\
(0.009)\end{array}$ \\
\hline Enrolled in School & $\begin{array}{l}0.033^{*} \\
(0.019)\end{array}$ & $\begin{array}{c}0.009 \\
(0.016)\end{array}$ & $\begin{array}{c}0.032^{* * *} \\
(0.010)\end{array}$ & $\begin{array}{l}0.033^{*} \\
(0.019)\end{array}$ & $\begin{array}{c}0.008 \\
(0.016)\end{array}$ & $\begin{array}{c}0.032^{* * *} \\
(0.010)\end{array}$ \\
\hline Has Finished College & $\begin{array}{c}0.022 \\
(0.027)\end{array}$ & $\begin{array}{l}-0.033 \\
(0.022)\end{array}$ & $\begin{array}{c}-0.030^{* * *} \\
(0.010)\end{array}$ & $\begin{array}{c}0.023 \\
(0.027)\end{array}$ & $\begin{array}{l}-0.032 \\
(0.022)\end{array}$ & $\begin{array}{c}-0.030^{* * *} \\
(0.010)\end{array}$ \\
\hline Northeast & $\begin{array}{l}-0.012 \\
(0.039)\end{array}$ & $\begin{array}{c}0.075^{* *} \\
(0.030)\end{array}$ & $\begin{array}{c}0.065^{* * *} \\
(0.017)\end{array}$ & $\begin{array}{l}-0.012 \\
(0.039)\end{array}$ & $\begin{array}{c}0.076^{* *} \\
(0.030)\end{array}$ & $\begin{array}{c}0.065^{* * *} \\
(0.017)\end{array}$ \\
\hline South & $\begin{array}{c}0.013 \\
(0.032)\end{array}$ & $\begin{array}{c}0.042^{* *} \\
(0.020)\end{array}$ & $\begin{array}{l}-0.005 \\
(0.012)\end{array}$ & $\begin{array}{c}0.013 \\
(0.032)\end{array}$ & $\begin{array}{c}0.042^{* *} \\
(0.020)\end{array}$ & $\begin{array}{l}-0.005 \\
(0.012)\end{array}$ \\
\hline West & $\begin{array}{c}-0.065^{*} \\
(0.035)\end{array}$ & $\begin{array}{c}-0.114^{* * *} \\
(0.035)\end{array}$ & $\begin{array}{c}-0.062^{* * *} \\
(0.016)\end{array}$ & $\begin{array}{c}-0.066^{*} \\
(0.035)\end{array}$ & $\begin{array}{c}-0.114^{* * *} \\
(0.035)\end{array}$ & $\begin{array}{c}-0.062^{* * *} \\
(0.016)\end{array}$ \\
\hline Mom College Graduate & $\begin{array}{c}0.003 \\
(0.039)\end{array}$ & $\begin{array}{l}-0.031 \\
(0.026)\end{array}$ & $\begin{array}{l}-0.009 \\
(0.012)\end{array}$ & $\begin{array}{c}0.003 \\
(0.039)\end{array}$ & $\begin{array}{l}-0.030 \\
(0.026)\end{array}$ & $\begin{array}{l}-0.009 \\
(0.012)\end{array}$ \\
\hline Dad College Graduate & $\begin{array}{l}-0.040 \\
(0.034)\end{array}$ & $\begin{array}{c}0.011 \\
(0.029)\end{array}$ & $\begin{array}{c}-0.042^{* * *} \\
(0.012)\end{array}$ & $\begin{array}{l}-0.040 \\
(0.034)\end{array}$ & $\begin{array}{c}0.011 \\
(0.029)\end{array}$ & $\begin{array}{c}-0.042^{* * *} \\
(0.012)\end{array}$ \\
\hline Urban & $\begin{array}{c}0.091^{* * *} \\
(0.027)\end{array}$ & $\begin{array}{l}-0.017 \\
(0.022)\end{array}$ & $\begin{array}{c}0.057^{* * *} \\
(0.010)\end{array}$ & $\begin{array}{c}0.091^{* * *} \\
(0.027)\end{array}$ & $\begin{array}{l}-0.017 \\
(0.022)\end{array}$ & $\begin{array}{c}0.057^{* * *} \\
(0.010)\end{array}$ \\
\hline Unemp (state) & $\begin{array}{c}0.022^{* *} \\
(0.009)\end{array}$ & $\begin{array}{c}0.013 \\
(0.008)\end{array}$ & $\begin{array}{c}0.031^{* * *} \\
(0.005)\end{array}$ & $\begin{array}{c}0.022^{* *} \\
(0.009)\end{array}$ & $\begin{array}{c}0.013 \\
(0.008)\end{array}$ & $\begin{array}{c}0.031^{* * *} \\
(0.005)\end{array}$ \\
\hline Housing Costs (HP/Y, state) & $\begin{array}{c}0.053^{* * *} \\
(0.009)\end{array}$ & $\begin{array}{c}0.044^{* * *} \\
(0.012)\end{array}$ & $\begin{array}{c}0.029 * * * \\
(0.007)\end{array}$ & $\begin{array}{c}0.053^{* * *} \\
(0.009)\end{array}$ & $\begin{array}{c}0.044^{* * *} \\
(0.012)\end{array}$ & $\begin{array}{c}0.029^{* * *} \\
(0.007)\end{array}$ \\
\hline Dummy 2008-2011 & $\begin{array}{l}-0.008 \\
(0.019)\end{array}$ & $\begin{array}{c}0.007 \\
(0.018)\end{array}$ & $\begin{array}{c}0.007 \\
(0.011)\end{array}$ & $\begin{array}{l}-0.013 \\
(0.020)\end{array}$ & $\begin{array}{l}-0.008 \\
(0.019)\end{array}$ & $\begin{array}{c}0.005 \\
(0.011)\end{array}$ \\
\hline Period No Work & $\begin{array}{l}0.025^{*} \\
(0.014)\end{array}$ & $\begin{array}{c}0.044^{* * *} \\
(0.012)\end{array}$ & $\begin{array}{c}0.073^{* * *} \\
(0.008)\end{array}$ & $\begin{array}{c}0.016 \\
(0.019)\end{array}$ & $\begin{array}{c}0.023 \\
(0.016)\end{array}$ & $\begin{array}{c}0.068^{* * *} \\
(0.011)\end{array}$ \\
\hline Dummy 2008-2011 × No Work & & & & $\begin{array}{c}0.016 \\
(0.022)\end{array}$ & $\begin{array}{c}0.038^{* *} \\
(0.018)\end{array}$ & $\begin{array}{c}0.008 \\
(0.013)\end{array}$ \\
\hline Constant & $\begin{array}{c}0.379 * * * \\
(0.041)\end{array}$ & $\begin{array}{c}0.418^{* * *} \\
(0.032)\end{array}$ & $\begin{array}{c}0.355^{* * *} \\
(0.015)\end{array}$ & $\begin{array}{c}0.383^{* * *} * \\
(0.041)\end{array}$ & $\begin{array}{c}0.427^{* * *} \\
(0.032)\end{array}$ & $\begin{array}{c}0.357^{* * *} * \\
(0.015)\end{array}$ \\
\hline Number & 10880 & 13872 & 25561 & 10880 & 13872 & 25561 \\
\hline Adj. R-squared. & 0.05 & 0.04 & 0.06 & 0.05 & 0.04 & 0.06 \\
\hline
\end{tabular}

Notes: These results are calculated using a linear probability model. The dependent variable, LWP, is 1 if the respondent reports a parent in the house he/she lives in during the interview. Standard errors clustered at the respondent level. Additional controls include a full set of age dummies from age 24 to age 31, with age 23 as the base category. "Period No Work" is a dummy variable that equals 1 if the respondent was out of work for more than ten weeks in the previous year and is zero otherwise. "Dummy 2008-2011" is an indicator variable that equals one for the years 2008 to 2011 and is zero otherwise. ${ }^{*} \mathrm{p}<0.10,{ }^{* *} \mathrm{p}<0.05,{ }^{* * *} \mathrm{p}<0.01$ 


\section{Appendix}

\subsection{Supplementary Data Sources}

- Housing Costs: Ratio of house prices to income by state and year as defined in the next section (sources outlined below).

- House Price Growth: Calculated based on state house price indexes published by CoreLogic.

- House Prices: Median house prices by state and year are extrapolated using data from the closest decennial census and the relevant state house price growth. For example, the median house price in state $\mathrm{X}$ in 1983 equals the median house value in state X in the 1980 Census multiplied by 1 plus the growth rate of house prices in state X between 1980 and 1983. Similarly, the median house price in state X in 1986 equals the median house value in state $\mathrm{X}$ in the 1990 Census deflated by 1 plus the growth rate in house prices in state X between 1986 and 1990. We use the prior census for years ending in " 5 " (e.g. 1980 Census for 1985 house prices) and use data from the American Community Survey (ACS) starting in 2006.

- Aggregate Income: Two sources: Per capita income by state from the Bureau of Economic Analysis (BEA); Median net income for individuals 20-30 years-old by state from the annual March CPS supplement. Tax burdens are calculated using the NBER's TAXSIM module.

- Unemployment: State-level unemployment rate data from the Bureau of Labor Statistics (BLS).

\subsection{Data Definitions}

\section{Housing Costs}

$$
\mathrm{HC}_{s t}=\frac{\mathrm{HP}_{s t}}{Y_{s t}}
$$

$\mathrm{HC}_{s t}$ is our measure of housing costs in state $s$ in year $t$; $\mathrm{HP}_{s t}$ is the median house price in state $s$ in year $t$; and $Y_{s t}$ is a measure of state-level income in year $t$.

Unless noted, we use median income for individuals who are 20-30 years-old as our measure of state income. This measure likely provides a more accurate account of young adults' purchasing power in a given state and year than overall median income for the state, since the latter is likely dominated by the earnings of prime-age workers - wages which are likely higher than those for individuals who are just starting their working careers. 


\subsection{Summary Statistics}

TABle A.1: Summary Statistics: All Sample Respondents

\begin{tabular}{lccccc}
\hline & Count & Mean & SD & Min & Max \\
\hline Living with Parents & 112,667 & 0.219 & 0.414 & 0.000 & 1.000 \\
Age of Respondent & 112,667 & 26.956 & 2.412 & 23.000 & 31.000 \\
Female & 112,667 & 0.507 & 0.500 & 0.000 & 1.000 \\
Enrolled in School & 112,667 & 0.097 & 0.296 & 0.000 & 1.000 \\
Has Finished College & 112,667 & 0.167 & 0.373 & 0.000 & 1.000 \\
Hispanic & 112,667 & 0.195 & 0.396 & 0.000 & 1.000 \\
Black & 112,667 & 0.271 & 0.444 & 0.000 & 1.000 \\
Non-Hispanic/Non-Black & 112,667 & 0.534 & 0.499 & 0.000 & 1.000 \\
Northeast & 112,667 & 0.173 & 0.378 & 0.000 & 1.000 \\
North Central & 112,667 & 0.231 & 0.421 & 0.000 & 1.000 \\
South & 112,667 & 0.380 & 0.485 & 0.000 & 1.000 \\
West & 112,667 & 0.216 & 0.411 & 0.000 & 1.000 \\
Mom College Graduate & 112,667 & 0.114 & 0.317 & 0.000 & 1.000 \\
Dad College Graduate & 112,667 & 0.146 & 0.353 & 0.000 & 1.000 \\
Rural & 112,667 & 0.219 & 0.414 & 0.000 & 1.000 \\
Unemployment, State & 112,667 & 6.568 & 2.055 & 2.317 & 13.658 \\
Housing Costs (HP/Y, state) & 112,667 & 5.743 & 3.364 & 1.652 & 20.650 \\
Urban/Rural Unknown & 112,667 & 0.023 & 0.150 & 0.000 & 1.000 \\
\hline
\end{tabular}


Table A.2: Summary Statistics: 1997 Cohort Sample

\begin{tabular}{lccccc}
\hline & & & & & \\
& Count & Mean & SD & Min & Max \\
\hline Living with Parents & 50,313 & 0.263 & 0.440 & 0.000 & 1.000 \\
Age of Respondent & 50,313 & 26.052 & 2.190 & 23.000 & 31.000 \\
Female & 50,313 & 0.499 & 0.500 & 0.000 & 1.000 \\
Enrolled in School & 50,313 & 0.147 & 0.354 & 0.000 & 1.000 \\
Has Finished College & 50,313 & 0.193 & 0.394 & 0.000 & 1.000 \\
Hispanic & 50,313 & 0.216 & 0.412 & 0.000 & 1.000 \\
Black & 50,313 & 0.276 & 0.447 & 0.000 & 1.000 \\
Non-Hispanic/Non-Black & 50,313 & 0.508 & 0.500 & 0.000 & 1.000 \\
Northeast & 50,313 & 0.161 & 0.367 & 0.000 & 1.000 \\
North Central & 50,313 & 0.217 & 0.412 & 0.000 & 1.000 \\
South & 50,313 & 0.393 & 0.488 & 0.000 & 1.000 \\
West & 50,313 & 0.230 & 0.421 & 0.000 & 1.000 \\
Mom College Graduate & 50,313 & 0.167 & 0.373 & 0.000 & 1.000 \\
Dad College Graduate & 50,313 & 0.179 & 0.383 & 0.000 & 1.000 \\
Urban & 50,313 & 0.736 & 0.441 & 0.000 & 1.000 \\
Unemployment, State & 50,313 & 7.023 & 2.477 & 2.567 & 13.658 \\
Housing Costs (HP/Y, state) & 50,313 & 6.401 & 3.806 & 1.906 & 20.650 \\
Weeks out of Work (Last Year) & 50,313 & 12.364 & 18.409 & 0.000 & 53.000 \\
Urban/Rural Unknown & 50,313 & 0.038 & 0.192 & 0.000 & 1.000 \\
\hline
\end{tabular}

Table A.3: Summary Statistics: 1979 Cohort Sample

\begin{tabular}{lccccc}
\hline & & & & & \\
& Count & Mean & SD & Min & Max \\
\hline Living with Parents & 62,354 & 0.184 & 0.387 & 0.000 & 1.000 \\
Age of Respondent & 62,354 & 27.685 & 2.335 & 23.000 & 31.000 \\
Female & 62,354 & 0.513 & 0.500 & 0.000 & 1.000 \\
Enrolled in School & 62,354 & 0.057 & 0.232 & 0.000 & 1.000 \\
Has Finished College & 62,354 & 0.145 & 0.352 & 0.000 & 1.000 \\
Hispanic & 62,354 & 0.178 & 0.383 & 0.000 & 1.000 \\
Black & 62,354 & 0.267 & 0.442 & 0.000 & 1.000 \\
Non-Hispanic/Non-Black & 62,354 & 0.555 & 0.497 & 0.000 & 1.000 \\
Northeast & 62,354 & 0.183 & 0.387 & 0.000 & 1.000 \\
North Central & 62,354 & 0.242 & 0.428 & 0.000 & 1.000 \\
South & 62,354 & 0.370 & 0.483 & 0.000 & 1.000 \\
West & 62,354 & 0.204 & 0.403 & 0.000 & 1.000 \\
Mom College Graduate & 62,354 & 0.070 & 0.256 & 0.000 & 1.000 \\
Dad College Graduate & 62,354 & 0.120 & 0.325 & 0.000 & 1.000 \\
Urban & 62,354 & 0.775 & 0.417 & 0.000 & 1.000 \\
Unemployment, State & 62,354 & 6.201 & 1.543 & 2.317 & 12.758 \\
Housing Costs (HP/Y, state) & 62,354 & 5.211 & 2.851 & 1.652 & 14.994 \\
Urban/Rural Unknown & 62,354 & 0.011 & 0.102 & 0.000 & 1.000 \\
\hline
\end{tabular}


TABle A.4: Living with Parents. Pooled Cohorts (Ages 16-31)

\begin{tabular}{|c|c|c|c|c|}
\hline & (1) & $(2)$ & $(3)$ & (4) \\
\hline 1997 Cohort $^{1}$ & $\begin{array}{c}0.059^{* * *} \\
(0.004)\end{array}$ & $\begin{array}{c}0.043^{* * *} \\
(0.004)\end{array}$ & $\begin{array}{c}0.028^{* * *} \\
(0.004)\end{array}$ & $\begin{array}{c}0.027^{* * *} \\
(0.004)\end{array}$ \\
\hline Female & & $\begin{array}{c}-0.084^{* * *} \\
(0.004)\end{array}$ & $\begin{array}{c}-0.092^{* * *} \\
(0.004)\end{array}$ & $\begin{array}{c}-0.092^{* * *} \\
(0.004)\end{array}$ \\
\hline Enrolled in School & & $\begin{array}{c}0.132^{* * *} \\
(0.004)\end{array}$ & $\begin{array}{c}0.122^{* * *} \\
(0.004)\end{array}$ & $\begin{array}{c}0.122^{* * *} \\
(0.004)\end{array}$ \\
\hline Has Finished College & & $\begin{array}{c}-0.035^{* * *} \\
(0.005)\end{array}$ & $\begin{array}{c}-0.035^{* * *} \\
(0.005)\end{array}$ & $\begin{array}{c}-0.034^{* * *} \\
(0.005)\end{array}$ \\
\hline Hispanic & & $\begin{array}{c}0.076^{* * *} \\
(0.005)\end{array}$ & $\begin{array}{c}0.069^{* * *} \\
(0.005)\end{array}$ & $\begin{array}{c}0.060^{* * *} \\
(0.006)\end{array}$ \\
\hline Black & & $\begin{array}{c}0.081^{* * *} \\
(0.005)\end{array}$ & $\begin{array}{c}0.082^{* * *} \\
(0.005)\end{array}$ & $\begin{array}{c}0.080^{* * *} \\
(0.005)\end{array}$ \\
\hline Northeast & & $\begin{array}{c}0.057^{* * *} \\
(0.006)\end{array}$ & $\begin{array}{c}0.052^{* * *} \\
(0.006)\end{array}$ & $\begin{array}{c}0.056^{* * *} \\
(0.006)\end{array}$ \\
\hline South & & $\begin{array}{c}-0.010^{* *} \\
(0.005)\end{array}$ & $\begin{array}{l}-0.005 \\
(0.005)\end{array}$ & $\begin{array}{l}-0.002 \\
(0.005)\end{array}$ \\
\hline West & & $\begin{array}{c}-0.036^{* * *} \\
(0.005)\end{array}$ & $\begin{array}{c}-0.069^{* * * *} \\
(0.006)\end{array}$ & $\begin{array}{c}-0.068^{* * *} \\
(0.006)\end{array}$ \\
\hline Mom College Graduate & & $\begin{array}{c}0.005 \\
(0.006)\end{array}$ & $\begin{array}{c}0.007 \\
(0.006)\end{array}$ & $\begin{array}{c}0.007 \\
(0.006)\end{array}$ \\
\hline Dad College Graduate & & $\begin{array}{l}-0.008 \\
(0.005)\end{array}$ & $\begin{array}{l}-0.007 \\
(0.005)\end{array}$ & $\begin{array}{l}-0.007 \\
(0.005)\end{array}$ \\
\hline Urban & & $\begin{array}{c}0.030^{* * *} \\
(0.004)\end{array}$ & $\begin{array}{c}0.027^{* * * *} \\
(0.004)\end{array}$ & $\begin{array}{c}0.029^{* * *} \\
(0.004)\end{array}$ \\
\hline Rural/Urban Unknown & & $\begin{array}{c}-0.152^{* * *} \\
(0.008)\end{array}$ & $\begin{array}{c}-0.032^{* * *} \\
(0.010)\end{array}$ & $\begin{array}{c}-0.030^{* * *} \\
(0.010)\end{array}$ \\
\hline Unemp (state) & & & $\begin{array}{c}0.015^{* * *} \\
(0.001)\end{array}$ & $\begin{array}{c}0.011^{* * *} \\
(0.002)\end{array}$ \\
\hline Housing Costs (HP/Y, state) & & & $\begin{array}{c}0.026^{* * *} \\
(0.002)\end{array}$ & $\begin{array}{c}0.020^{* * *} \\
(0.003)\end{array}$ \\
\hline Hispanic $\times$ Unemp (state) & & & & $\begin{array}{c}0.009^{* *} \\
(0.004)\end{array}$ \\
\hline Black $\times$ Unemp (state) & & & & $\begin{array}{c}0.008^{* *} \\
(0.003)\end{array}$ \\
\hline Hispanic $\times \mathrm{HP} / \mathrm{Y}$ & & & & $\begin{array}{c}0.022^{* * *} \\
(0.004)\end{array}$ \\
\hline Black $\times \mathrm{HP} / \mathrm{Y}$ & & & & $\begin{array}{l}-0.008 \\
(0.005)\end{array}$ \\
\hline Constant & $\begin{array}{c}0.905^{* * *} \\
(0.003)\end{array}$ & $\begin{array}{c}0.779 * * * \\
(0.007)\end{array}$ & $\begin{array}{c}0.818^{* * *} \\
(0.007)\end{array}$ & $\begin{array}{c}0.815^{* * *} \\
(0.007)\end{array}$ \\
\hline Number & 250509 & 250509 & 243323 & 243323 \\
\hline Adj. R-squared. & 0.26 & 0.29 & 0.30 & 0.30 \\
\hline
\end{tabular}

Notes: These results are calculated using a linear probability model. The dependent variable, LWP, is 1 if the respondent reports a parent in the house he/she lives in during the interview. ${ }^{1}$ Indicator variable that takes a value of 1 if the respondent is in the 1997 cohort and 0 if the respondent is in the 1979 cohort. Standard errors clustered at the respondent level. Housing costs are measured relative to total statelevel median income rather than the income of 20-to-30 year-old individuals due to the age range of the sample and data availability. Additional controls include a full set of age dummies from age 17 to age 31 , with age 16 as the base category. * $\mathrm{p}<0.10,{ }^{* *} \mathrm{p}<0.05,{ }^{* * *} \mathrm{p}<0.01$ 